\title{
Food preservation techniques and nanotechnology for increased shelf life of fruits, vegetables, beverages and spices: a review
}

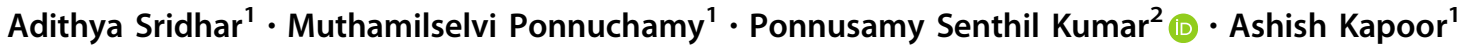

Received: 15 September 2020 / Accepted: 17 October 2020/Published online: 9 November 2020

(c) Springer Nature Switzerland AG 2020

\begin{abstract}
Food wastage is a major issue impacting public health, the environment and the economy in the context of rising population and decreasing natural resources. Wastage occurs at all stages from harvesting to the consumer, calling for advanced techniques of food preservation. Wastage is mainly due to presence of moisture and microbial organisms present in food. Microbes can be killed or deactivated, and cross-contamination by microbes such as the coronavirus disease 2019 (COVID-19) should be avoided. Moisture removal may not be feasible in all cases. Preservation methods include thermal, electrical, chemical and radiation techniques. Here, we review the advanced food preservation techniques, with focus on fruits, vegetables, beverages and spices. We emphasize electrothermal, freezing and pulse electric field methods because they allow both pathogen reduction and improvement of nutritional and physicochemical properties. Ultrasound technology and ozone treatment are suitable to preserve heat sensitive foods. Finally, nanotechnology in food preservation is discussed.
\end{abstract}

Keywords Food preservation · Electrothermal · Freezing · Ultrasound · Ozone treatment · Pulse electric field . Nanotechnology

Abbreviations
$\begin{array}{ll}\text { ReFED } & \text { Rethink Food Waste Through Economics and } \\ & \text { Data } \\ \text { GAE } & \text { Gallic acid equivalent } \\ \text { TPC } & \text { Total phenolic content } \\ \text { FDA } & \text { Food and Drug Administration } \\ \text { GRAS } & \text { Generally recognized as safe } \\ \text { EFSA } & \text { European Food Safety Authority }\end{array}$

Ponnusamy Senthil Kumar

senthilkumarp@ssn.edu.in; senthilchem8582@gmail.com

$\triangle$ Ashish Kapoor

ashishko@srmist.edu.in

1 Department of Chemical Engineering, College of Engineering and Technology, Faculty of Engineering and Technology, SRM Institute of Science and Technology, SRM Nagar, Kattankulathur, 603203 Kanchipuram, Chennai, India

2 Department of Chemical Engineering, Sri Sivasubramaniya Nadar College of Engineering, Chennai 603110, India

\section{Introduction}

Food is vital for human survival and development. A recent review shows that food transmission of the coronavirus disease 2019 (COVID-19) is overlooked (Han et al. 2020). Food can be consumed in raw or processed form to obtain energy and sustain growth. Food wastage has become a major issue worldwide in the recent times. A considerable amount of food gets wasted at various stages of the food production and consumption chain. According to the report of Rethink Food Waste Through Economics and Data (ReFED), the data in Fig. 1 show the food wastage distribution for various types of food materials (ReFED 2016). Globally, due to inefficient supply chains, rising population and climate change, a large number of people are deprived of food on regular basis (Leisner 2020). Griffin et al. (2009) showed a detailed study about the waste generation of different food communities. Out of the food waste generated, $20 \%$ comprised production waste, $1 \%$ of processing waste, $19 \%$ of distribution and $60 \%$ of consumer generated waste. The major reasons for wastage were due to shrinkage of food while cooking, manufacturing issues, supply chain barriers, high consumer standards, changing climatic conditions, soil runoffs and 
Fig. 1 Food wastage for different food materials based on weight percentage. The demand for variety and abundance as well as inefficient storage conditions increases the amount of overall food wastage. Fruits and vegetables are among the least expensive and fastest spoiling foods followed by milk and dairy products. Data from ReFED (2016)

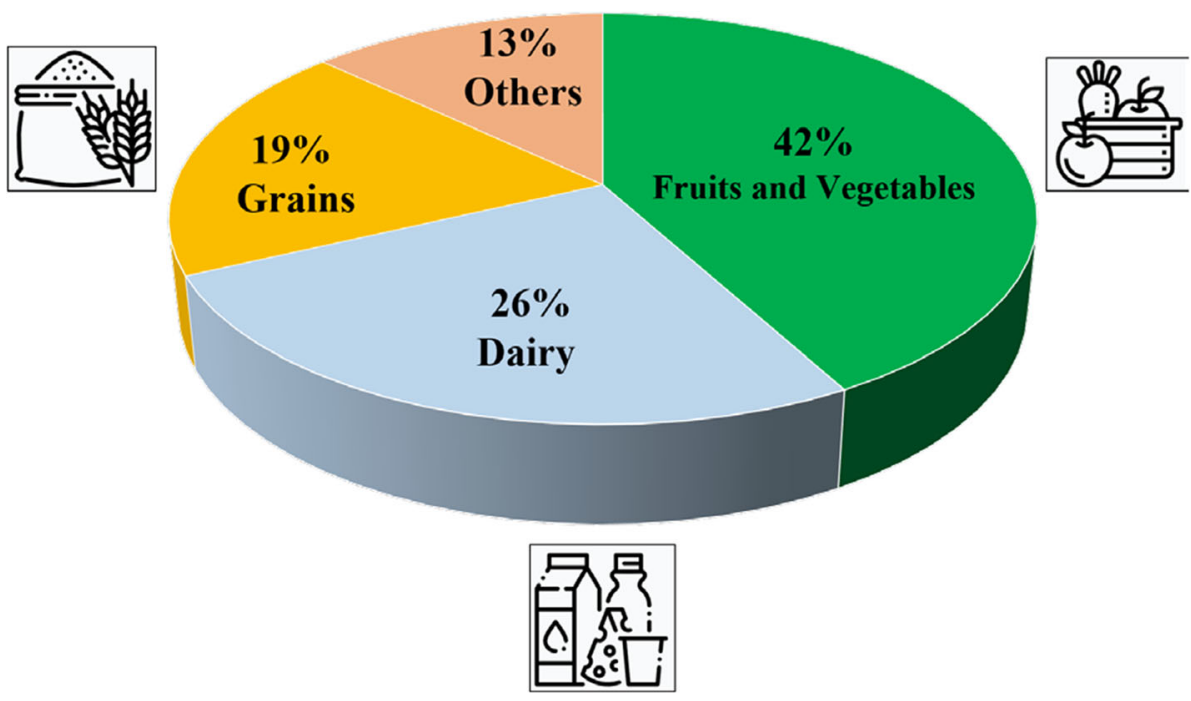

policy constraints (Bräutigam et al. 2014; Silvennoinen et al. 2014; Filimonau and De Coteau 2019; GomezZavaglia et al. 2020).

A recent analysis conducted in Finland in 2019 found more than $50 \%$ of the food waste is from households (Filimonau and De Coteau 2019). The decision between 'best before' or 'use by' was a tough call to take in determining shelf life of product for the customers.

However, with the increase in population, consumers demand food that is fresh, healthy and nutritious. Although enough food is produced every day to feed the world, the technology and food produced fails to reach those in need. Thus, food wastage has become a key challenge to in all food processing sectors.

Any kind of food when harvested begins to show spoilage responses. One of the sustainable solutions to counter the food wastage issues is food preservation. The idea of food preservation was introduced in the ancient times when our ancestors were finding ways to keep the food fresh and edible. Concepts like sun drying, salting and pasteurization were introduced depending on climatic and seasonal factors. Preservation enabled humans to form communities, stopped them from killing animals and brought about a leisure attitude keeping food for additional time.

Rapid industrialization and advent of lean methods paved the way for processes like thermal treatment, canning and freezing which gave a better shelf life extension by controlling the pathogens. However, food safety and security became a major concern due to the growing population and increasing consumer standards and demands providing healthy and nutritious food (Saravanan et al. 2020). Thus, the concept of preserving food grew rapidly with an aim to provide food to all. The goal of food preservation is to inhibit any biochemical reactions and to restrict entry of bacteria or fungi. The technique allows minimization of wastage with improved shelf life extension. Some of the popular conventional preservation techniques like heating, drying and freezing have been implemented in large industries (Pereira et al. 2018; Białkowska et al. 2020; Said 2020). However, it has been found that there are certain disadvantages in heat treatment and freezing methods such as food shrinkage, texture and nutrient loss and organic properties leading to a huge overall loss in the food product (Jayasena et al. 2015).

In the recent years, chemical and microbiological treatments have been carried out with additives, coatings and various polyphenolic plant extracts thus posing an effective solution to food preservation. There is a lack of research in bridging the gap between the food wastage and food preservation techniques. This review investigates the upcoming food preservation technologies which are likely to play a dominant role in the food preservation industry. Current trends and advancements in preservation techniques and their applications to foods including fruits, vegetables, liquid foods and spices are the key aspects discussed here. The review covers a wide range of changes brought in conventional technologies and current technologies in the above fields. Special focus is also given to nanotechnology with its application in foods, agriculture and packaging sectors. The data have been collected after an extensive literature search over the subject surveyed for the last 15 years taking into account the challenges faced in industry during preservation. This work could be a perfect platform for understanding the advancements in food preservation techniques and its relevance to industry. The advent of nanotechnology in research and a combination of various advanced technologies as discussed in the literature (Butnaru et al. 2019; Nile et al. 2020; Rech et al. 2020; Tsironi et al. 2020) as well as in this manuscript could be the "go-to" technologies in the future. Thus, positive steps 
need to be taken to narrow down on the enhancements of these technologies for having a sustainable and cost-effective lifestyle.

\section{Prevalent food preservation technologies}

\section{Thermal treatment}

Heat or thermal treatment is considered as one of the novel techniques for food preservation. For many years, the technique is well proven in various food sectors: from bakery and dairy to fruits and vegetables (Wurlitzer et al. 2019; Gharibi et al. 2020; Prieto-Santiago et al. 2020; Christiansen et al. 2020). The process generally involves heating of foods at a temperature between 75 and $90{ }^{\circ} \mathrm{C}$ or higher with a holding time of 25-30 s. Study on preservation enhancement of apple juice beverage by pasteurization and thermal treatment of maize showed a great impact on the flavor, digestibility, glycemic index, aroma, color and sensory attributes (Charles-Rodríguez et al. 2007; Zou et al. 2020). A recent report also highlighted five different types of rice when undergoing hydrothermal treatment showing results in par with respect to the quality of market rice (Bhattacharyya and Pal 2020).

The heating of foods reduces the pathogens. However, extensive research has also concluded nutrient losses, energy wastages, flavor changes and reduction in the food matrix (Roselló-Soto et al. 2018). A study conducted on light and dark honey showed changes in physicochemical characteristics, antioxidant activities and nutrient variations post-treatment (Nayik and Nanda 2016; Zarei et al. 2019). Liquid foods, juices and beverages too have a negative impact causing gelatinization and browning reactions (Codina-Torrella et al. 2017; de Souza et al. 2020). Over the years, constant investigation has been done on optimization studies of heat on exposure of food to improve its shelf life. Adjustments and slight modification to former technologies have recently contributed to significant advances with a combination of electrical and thermal methods. Different processes like electroplasmolysis, ohmic heating, and microwave heating of foods have created a dramatic impact in the food industry advancements. Table 1 shows the advanced electrothermal treatment techniques applied to different foods.

\section{Freezing}

Cooling and freezing of products have been extensively applied for preservation of leafy vegetables, spices and milk products to maintain the sensorial attributes and nutrition qualities. Extensively used freezing techniques involve air blast, cryogenic, direct contact and immersion freezing, while advanced techniques involve high pressure freezing, ultrasound assisted freezing, electromagnetic disturbance freezing and dehydration freezing (Cheng et al. 2017; Barbosa de Lima et al. 2020). Cooling and freezing process mainly relies on the process of heat transfer. During cooling, there is a transfer of heat energy from the food and packaged container to the surrounding environment leading to an agreement of cooling. Thus, thermal conductivity and thermal diffusivity greatly affect the cooling or freezing rate. During the recent years, the storage technique has gained significant interest with the start of ready-to-eat foods catering to the needs of the consumer. The foods with their appropriate packaging material and cool temperature will always inhibit entry of microorganisms as well as maintain food safety. Although cooling and freezing are effective in their own terms, cooling time, uneven speed of ice crystal formation, storage expenses and specialized environments are concerning issues. In order to understand and overcome these challenges, technological tools like three-dimensional mathematical models and computational fluid dynamics models were evaluated to understand the heat transfer and fluid flow patterns with various food formulations thus showing an approach to minimize the issue (Zhu et al. 2019a, b; Barbosa de Lima et al. 2020; Brandão et al. 2020; Stebel et al. 2020). Table 2 shows a description of the various advanced freezing techniques applied to different foods.

\section{Ultrasound}

Ultrasound treatment involves use of high intensity and frequency sound waves which are passed into food materials. The efficient technology is chosen due to its simplicity in the equipment usage and being low cost as compared to other advanced instruments. The versatility of ultrasound is shown in its application in different fields ranging from medicine, healthcare to food industry (Dai and Mumper 2010).

Figure 2 illustrates a representation of different types of sonicators used for powdered and liquid foods. The process deals with ultrasonic radiation passing through the target solution. This action causes a disturbance in the solid particles in the solution leading to particles breaking and diffusing into the solvent (Cares et al. 2010). It should be noted that the intensity of the technique should be kept constant. This is because as intensity increases, intramolecular forces break the particle-particle bonding resulting in solvent penetrating between the molecules, a phenomenon termed as cavitation (Fu et al. 2020; Khan et al. 2020). Further enhancement of ultrasound extraction is dependent on factors like improved penetration, cell disruption, better swelling capacity and enhanced capillary effect (Huang et al 2020; Xu et al 2007). Table 3 shows the 
Table 1 Advanced electrothermal treatment techniques used in the food industry

\begin{tabular}{|c|c|c|c|c|}
\hline \multirow{2}{*}{$\begin{array}{l}\text { Advanced } \\
\text { techniques }\end{array}$} & \multirow[t]{2}{*}{ Technology involved } & \multicolumn{2}{|c|}{ Application in food materials } & \multirow[t]{2}{*}{ References } \\
\hline & & Sample(s) analyzed & Conclusions & \\
\hline \multirow[t]{2}{*}{ Electroplasmolysis } & \multirow[t]{2}{*}{$\begin{array}{l}\text { Involves effective destruction of cell } \\
\text { membrane matrix of different food } \\
\text { materials with help of high electric } \\
\text { current } \\
\text { Helpful in increasing the efficiency of } \\
\text { extraction }\end{array}$} & $\begin{array}{l}\text { Apple, cucumber, pear, } \\
\text { carrot, banana } \\
\text { (Pear, banana: } \\
900-1100 \mathrm{~V} / \mathrm{cm} \\
\text { Apple, cucumber, } \\
\text { carrot: } 200-400 \mathrm{~V} / \\
\text { cm) }\end{array}$ & $\begin{array}{l}\text { Electric field higher for cells having } \\
\text { secondary cell wall }\end{array}$ & $\begin{array}{l}\text { Bazhal et al. } \\
\text { (2003) }\end{array}$ \\
\hline & & $\begin{array}{l}\text { Tomato } \\
\text { Range of field strength } \\
\text { test: } 36-108 \mathrm{~V} / \mathrm{cm} \\
\text { Treatment time: } 5-30 \mathrm{~s}\end{array}$ & $\begin{array}{l}\text { Enzyme inactivation of pectin } \\
\text { methyl esterase and Aspergillus } \\
\text { niger decreased with increased in } \\
\text { treatment time at } 108 \mathrm{~V} / \mathrm{cm} \\
\text { Highest amount of pectin obtained } \\
\text { was } 3.56 \% \text { at } 36 \mathrm{~V} / \mathrm{cm} \text { for } 80 \mathrm{~s}\end{array}$ & $\begin{array}{l}\text { Yildiz and } \\
\text { Baysal( 2006) }\end{array}$ \\
\hline \multirow[t]{3}{*}{$\begin{array}{l}\text { Microwave } \\
\text { heating } \\
\text { (post- } \\
\text { pasteurization) }\end{array}$} & \multirow[t]{3}{*}{$\begin{array}{l}\text { Involves absorption of electromagnetic } \\
\text { energy leading to a temperature } \\
\text { increase of the food (due to high } \\
\text { dielectric capacity) thus improving } \\
\text { the product quality } \\
\text { Microwave heating is greatly } \\
\text { influenced by shape, size, food matrix } \\
\text { and equipment }\end{array}$} & $\begin{array}{l}\text { Gurum } \\
\text { (Citrulluslanatus var. } \\
\text { Colocynthoide) } \\
\text { Microwave power: } \\
800 \mathrm{~W} \\
\text { Time: } 6 \mathrm{~min} \\
\text { Frequency: } 2450 \mathrm{MHz}\end{array}$ & $\begin{array}{l}\text { Increase in polyphenol content from } \\
22.6 \text { to } 25.3 \mathrm{mg} \text { Gallic acid } \\
\text { equivalent }(\mathrm{GAE}) / \mathrm{kg} \text { oil } \\
\text { Increase in antioxidant activity } \\
\text { from } 59.2-64.7 \%\end{array}$ & $\begin{array}{l}\text { Karrar et al. } \\
\quad(2020)\end{array}$ \\
\hline & & $\begin{array}{l}\text { Saffron } \\
\text { Temperature: } 45-125^{\circ} \mathrm{C} \\
\text { Time: } 10-30 \text { min } \\
\text { Solvent concentration: } \\
\text { Ethanol }(0-100 \mathrm{v} / \mathrm{v} \\
\%)\end{array}$ & $\begin{array}{l}\text { Process conditions of } 95.15{ }^{\circ} \mathrm{C} \text {, } \\
30 \text { min and ethanol concentration } \\
\text { of } 59.5 \% \text { was considered } \\
\text { optimum for microwave heating }\end{array}$ & $\begin{array}{l}\text { Sarfarazi et al. } \\
(2020)\end{array}$ \\
\hline & & $\begin{array}{l}\text { Apple juice } \\
\text { Power: } 270-900 \mathrm{~W} \\
\text { Frequency: } 2450 \mathrm{MHz} \\
\text { Treatment time: } 83{ }^{\circ} \mathrm{C} \\
\text { for } 30 \mathrm{~s}\end{array}$ & $\begin{array}{l}\text { Reduction in microbes ( } E \text { coli) } \\
\text { post-microwave treatments } \\
\text { Treatment between } 720-900 \mathrm{~W} \text { for } \\
60-90 \mathrm{~s} \text { showed } 2 \text { to } 4 \mathrm{log} \\
\text { population reduction in microbes }\end{array}$ & $\begin{array}{l}\text { Cañumir et al. } \\
\text { (2002) }\end{array}$ \\
\hline \multirow[t]{3}{*}{ Ohmic heating } & \multirow[t]{3}{*}{$\begin{array}{l}\text { Involves heating of the food by the } \\
\text { passage of electric current. The food } \\
\text { product acts as an electric resistance } \\
\text { thus heating the whole matrix } \\
\text { Higher the voltage applied, better the } \\
\text { more the heat generated }\end{array}$} & $\begin{array}{l}\text { Orange juice } \\
\text { Temperature: } 40-95{ }^{\circ} \mathrm{C} \\
\text { Time: } 60 \mathrm{~s}\end{array}$ & $\begin{array}{l}\text { Comparison between conventional } \\
\text { thermal heating and ohmic } \\
\text { heating showed changes in the } \\
\text { antioxidant activity (ascorbic } \\
\text { acid) } \\
7 \% \text { decrease observed at } 42 \mathrm{~V} / \mathrm{cm} \text {, } \\
69^{\circ} \mathrm{C} \\
11 \% \text { decrease observed at } 44 \mathrm{~V} / \mathrm{cm} \text {, } \\
70^{\circ} \mathrm{C}\end{array}$ & $\begin{array}{l}\text { Demirdöven } \\
\text { and Baysal } \\
(2014) \text {; Salari } \\
\text { and Jafari } \\
\text { (2020) }\end{array}$ \\
\hline & & $\begin{array}{l}\text { Tomato juice } \\
\text { Conventional heating: } \\
75-300 \mathrm{~s} \\
\text { Ohmic heating: } 15-60 \mathrm{~s}\end{array}$ & $\begin{array}{l}\text { Lycopene presence observation and } \\
\text { detection and comparison } \\
\text { between conventional and ohmic } \\
\text { heating } \\
\text { Conventional: } 20.5-23.3 \% \text { increase } \\
\text { observed } \\
\text { Ohmic heating: } 21.3-23.6 \%\end{array}$ & $\begin{array}{l}\text { Makroo et al. } \\
\text { (2020); Salari } \\
\text { and Jafari } \\
(2020)\end{array}$ \\
\hline & & $\begin{array}{l}\text { Orange juice } \\
\text { Hot water treatment: } \\
90^{\circ} \mathrm{C}, 15-60 \mathrm{~s}\end{array}$ & $\begin{array}{l}\text { Cartenoids detection } \\
\text { Hot water: } 2.3-3.9 \% \text { decrease in } \\
\text { carotenoids }\end{array}$ & $\begin{array}{l}\text { Funcia et al. } \\
\text { (2020); } \\
\text { Makroo et al. } \\
(2020)\end{array}$ \\
\hline
\end{tabular}


Table 2 Advanced freezing techniques widely applied for different foods

\begin{tabular}{|c|c|c|c|c|}
\hline \multirow{2}{*}{$\begin{array}{l}\text { Advanced freezing } \\
\text { techniques }\end{array}$} & \multirow[t]{2}{*}{ Technology involved } & \multicolumn{2}{|l|}{ Application in foods } & \multirow[t]{2}{*}{ References } \\
\hline & & Sample & Conclusions & \\
\hline \multirow[t]{2}{*}{ High-pressure freezing } & $\begin{array}{l}\text { Involves freezing water at high } \\
\text { pressure below } 0{ }^{\circ} \mathrm{C} \text { so that it } \\
\text { forms small ice crystals } \\
\text { instantly once the pressure is } \\
\text { released } \\
\text { Process takes place with the } \\
\text { absence of heat }\end{array}$ & $\begin{array}{l}\text { Comparison of sugar-rich } \\
\text { dairy-based food foams } \\
\text { (ice creams) and a non- } \\
\text { aerated liquid system } \\
\text { Maximum pressure } \\
\text { applied: } 360 \mathrm{MPa} \text { at } \\
-25^{\circ} \mathrm{C}\end{array}$ & $\begin{array}{l}\text { Volume fraction of the air after } \\
\text { treatment }-78 \% \\
\text { Crystal size reduction- } 40 \mu \mathrm{m} \text { to } \\
34 \mu \mathrm{m} \\
\text { Overall improvements in sensorial } \\
\text { properties }\end{array}$ & $\begin{array}{l}\text { Volkert et al. } \\
\text { (2012); You } \\
\text { et al. (2020) }\end{array}$ \\
\hline & $\begin{array}{l}\text { Crystallization occurs instantly } \\
\text { once high pressure is released } \\
\text { Preservation of original properties } \\
\text { and quality improvements } \\
\text { noticed }\end{array}$ & $\begin{array}{l}\text { Kombu seaweed } \\
\text { (Laminaria } \\
\text { ochroleuca) } \\
\text { Process conditions: } 5{ }^{\circ} \mathrm{C} \text {, } \\
400-600 \mathrm{MPa}, 5 \mathrm{~min} \\
\text { followed by } \\
\text { refrigeration at } 5{ }^{\circ} \mathrm{C} \text { or } \\
\text { freezing at }-24^{\circ} \mathrm{C}\end{array}$ & $\begin{array}{l}\text { Comparison of salted and unsalted } \\
\text { seaweed } \\
\text { Detection of } 103 \text { volatile } \\
\text { compounds found. Major } \\
\text { compounds detected were } \\
\text { aldehydes, alcohols, } \\
\text { ketones, alkanes, } \\
\text { alkenes, and acids } \\
\text { Freezing lowered levels of } \\
\text { hydrocarbons, alkanes and } \\
\text { thiazoles } \\
\text { Salting increased levels of acids, } \\
\text { alcohols, pyranones, lactones and } \\
\text { thiazoles }\end{array}$ & $\begin{array}{l}\text { López-Pérez } \\
\text { et al. (2020) }\end{array}$ \\
\hline \multirow[t]{3}{*}{$\begin{array}{l}\text { Ultrasound-assisted } \\
\text { freezing }\end{array}$} & $\begin{array}{l}\text { Involves passing of sound waves } \\
\text { in between the food. Can be of } \\
\text { low frequency }(<100 \mathrm{kHz}) \text { or } \\
\text { high frequency }(20-100 \mathrm{kHz}) \\
\text { No destruction of food }\end{array}$ & $\begin{array}{l}\text { Cantaloupe melon juice } \\
\text { (Microcystis } \\
\text { aeruginosa) }\end{array}$ & $\begin{array}{l}\text { Testing for probiotic substrate } \\
\text { Lactobacillus casei } \\
\text { Study done for a period of } 42 \text { days } \\
\text { at } 4{ }^{\circ} \mathrm{C} \\
\text { Reduced caloric value observed }\end{array}$ & $\begin{array}{l}\text { Zendeboodi } \\
\text { et al. (2020) }\end{array}$ \\
\hline & $\begin{array}{l}\text { Intensity, frequency of ultrasound, } \\
\text { position of samples, cooling } \\
\text { medium temperature key } \\
\text { parameters for the process } \\
\text { Can be used to treat both solid and } \\
\text { liquid samples }\end{array}$ & $\begin{array}{l}\text { Grape juice } \\
\text { Amplitude of } 50 \% \text { and } \\
70 \% \text { with treatment } \\
\text { times of } 0,2.5 \text { and } \\
5 \text { min } \\
\text { Temperature } \\
\text { maintenance: } 50-80{ }^{\circ} \mathrm{C}\end{array}$ & $\begin{array}{l}\text { Comparison of ultrasound and } \\
\text { pasteurization treatment was } \\
\text { done } \\
\text { Total phenolic content (TPC) was } \\
\text { same for both the treatments at } \\
10 \text { min with amplitude of } 70 \% \\
\text { pH decreased and total soluble } \\
\text { solids increased with amplitude } \\
\text { and treatment time } \\
\text { Results indicated usefulness of } \\
\text { juice sonication to enhance } \\
\text { inactivation of pathogens }\end{array}$ & $\begin{array}{l}\text { Margean et al. } \\
(2020)\end{array}$ \\
\hline & & Pomegranate juice & $\begin{array}{l}\text { Results showed ultraviolet } 5.1 \mathrm{~W} / \\
\mathrm{cm}^{2} \text { dosage, } 3.5 \mathrm{~L} / \mathrm{min} \text { flow rate } \\
\text { and } 50{ }^{\circ} \mathrm{C} \text { microbes were below } \\
\text { the detection limits } \\
\text { Lower temperatures could reduce } \\
\text { the microbial activity preserving } \\
\text { the bioactive compounds }\end{array}$ & $\begin{array}{l}\text { Khan et al. } \\
\text { (2020); } \\
\text { Alabdali et al } \\
\text { (2020) }\end{array}$ \\
\hline \multirow[t]{2}{*}{ Radioactive freezing } & $\begin{array}{l}\text { Not predominantly used in } \\
\text { freezing } \\
\text { Radio waves generate a turning }\end{array}$ & $\begin{array}{l}\text { Onion, potato, ginger, } \\
\text { carrot } \\
\text { Dosage: } 0.05-0.15 \mathrm{kGy}\end{array}$ & $\begin{array}{l}\text { Inhibition of sprouting } \\
\text { Shelf life enhancement }\end{array}$ & Prakash (2016) \\
\hline & $\begin{array}{l}\text { force in the water molecule, and } \\
\text { an ice cluster is created due to } \\
\text { dielectric and dipolar properties } \\
\text { of water }\end{array}$ & $\begin{array}{l}\text { Cereals, fruits } \\
\text { Dosage: } 0.15-0.5 \mathrm{kGy}\end{array}$ & $\begin{array}{l}\text { Phytosanitation } \\
\text { Sterilization purposes } \\
\text { Mycotoxin decontamination } \\
\text { observed most effect with } \\
\text { advantages in nutrient qualities }\end{array}$ & $\begin{array}{l}\text { Ravindran and } \\
\text { Jaiswal } \\
\text { (2019); } \\
\text { Mousavi } \\
\text { Khaneghah } \\
\text { et al. (2020) }\end{array}$ \\
\hline
\end{tabular}


Table 2 (continued)

\begin{tabular}{|c|c|c|c|c|}
\hline \multirow{2}{*}{$\begin{array}{l}\text { Advanced freezing } \\
\text { techniques }\end{array}$} & \multirow[t]{2}{*}{ Technology involved } & \multicolumn{2}{|l|}{ Application in foods } & \multirow[t]{2}{*}{ References } \\
\hline & & Sample & Conclusions & \\
\hline $\begin{array}{l}\text { Dehydration freezing } \\
\text { or } \\
\text { osmodehydrofreezing }\end{array}$ & $\begin{array}{l}\text { Involves osmotic dehydration and } \\
\text { freezing techniques } \\
\text { Food is first dehydrated (water } \\
\text { removal) and immediately } \\
\text { frozen } \\
\text { Shelf life extension observed due } \\
\text { to accelerated freezing process } \\
\text { Low energy consumption, low } \\
\text { cost of packaging }\end{array}$ & $\begin{array}{l}\text { Mango } \\
\text { (Unripe vs Ripe "Kent" } \\
\text { mangoes) } \\
\text { Treatment: } 50{ }^{\circ} \mathrm{C} \text { in } 60 \\
\text { brix sugar solution with } \\
2 \mathrm{~g} \text { calcium lactate/ } \\
100 \mathrm{~g} \text { with pectin } \\
\text { methyl esterase } \\
\text { Pineapple with sucrose } \\
\text { syrup } \\
\text { Treatment: } 2 \mathrm{~h} \text { at } 40{ }^{\circ} \mathrm{C}\end{array}$ & $\begin{array}{l}\text { Unripe mangoes showed two- to } \\
\text { fivefold soluble solid gain as } \\
\text { compared to ripe } \\
\text { Unripe samples had lowest water } \\
\text { loss with reduction in lightness. } \\
\text { Ripe samples were stable } \\
\text { Pectin methyl esterase improved } \\
\text { rigidity in mangoes } \\
\text { Changes in pH, total acidity, } \\
\text { soluble solids, and water } \\
\text { observed } \\
\text { Dry matter content increase during } \\
\text { multiple stage } \\
\text { osmodehydrofreezingStudy } \\
\text { conducted showed multistage } \\
\text { osmodehydrofreezing gave better } \\
\text { performance than single stage } \\
\text { osmodehydrofreezing }\end{array}$ & $\begin{array}{l}\text { Fernández et al. } \\
\text { (2020) }\end{array}$ \\
\hline
\end{tabular}

Fig. 2 Types of ultrasound treatments: bath sonicator and probe sonicator. The treatment works on the principle of cavitation in which there is an energy transfer among food particles leading to bubble formation and collapsing. The technique requires minimal power providing more efficiency than traditional drying methods. It is used for treating various powdered or liquid foods

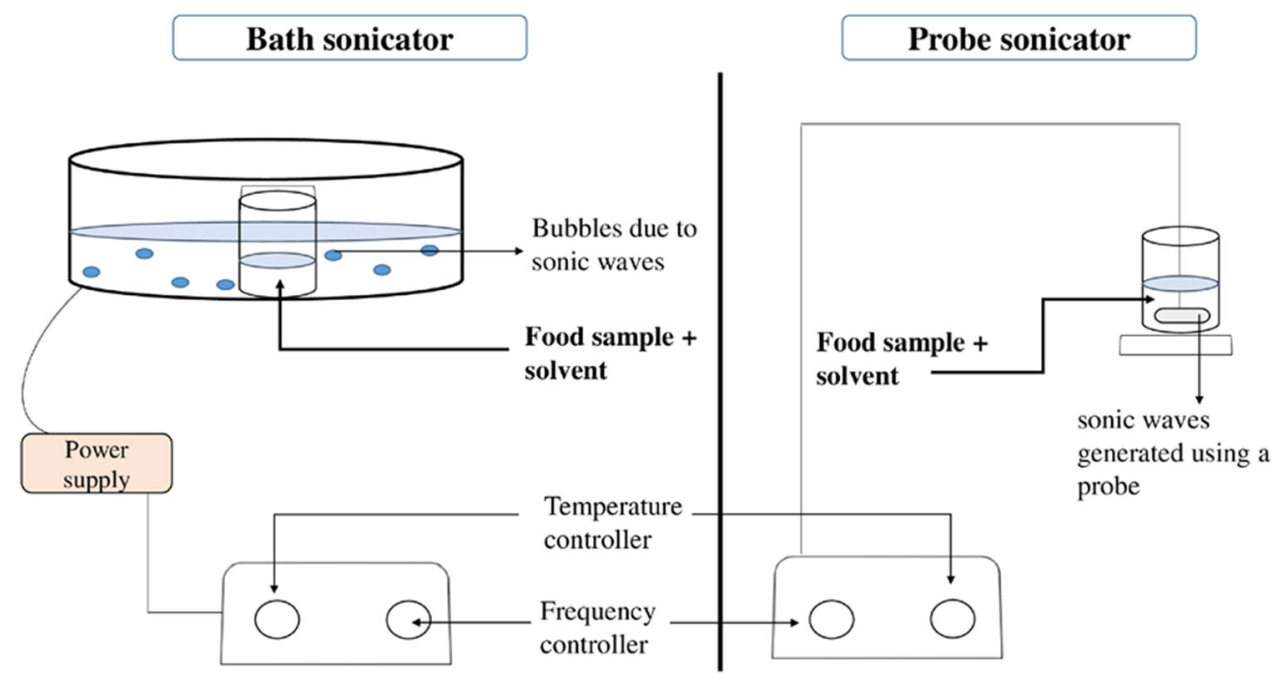

types of ultrasound technologies available which have created paths for efficiency improvements.

Ultrasound is slowly paving way into two most thriving sectors in the food industry, namely wine making and dairy production. Figure 3 shows the thermosonication process widely used in processing of milk and wine.

Milk is generally pasteurized in various industries to prevent spoilage and kill the microorganisms present. The utilization of a low-frequency ultrasound or combination of thermosonication (to $11.1 \mathrm{~s}$ ) or manothermosonication could enhance the safety, quality and functional properties of product by $5 \log$ times (Bermúdez-Aguirre et al. 2009;
Deshpande and Walsh 2020; Gammoh et al. 2020). Lowfrequency ultrasound alone has also played a significant role in improving the textural and homogenization effects of yoghurt, cheese and skimmed milk (Yang et al. 2020). With a shorter time interval, and thermosonication-applied $\left(20 \mathrm{kHz}, 480 \mathrm{~W}, 55^{\circ} \mathrm{C}\right)$ production was improved to $40 \%$ and also had a positive impact on its organoleptic properties (Tribst et al. 2020).

Production of wine fermentation and alcoholic drinks always faces an issue in tackling microorganisms or yeast. Conventional methods generally involve use of chemical preservatives like sulfur oxide to prevent spoilage or 


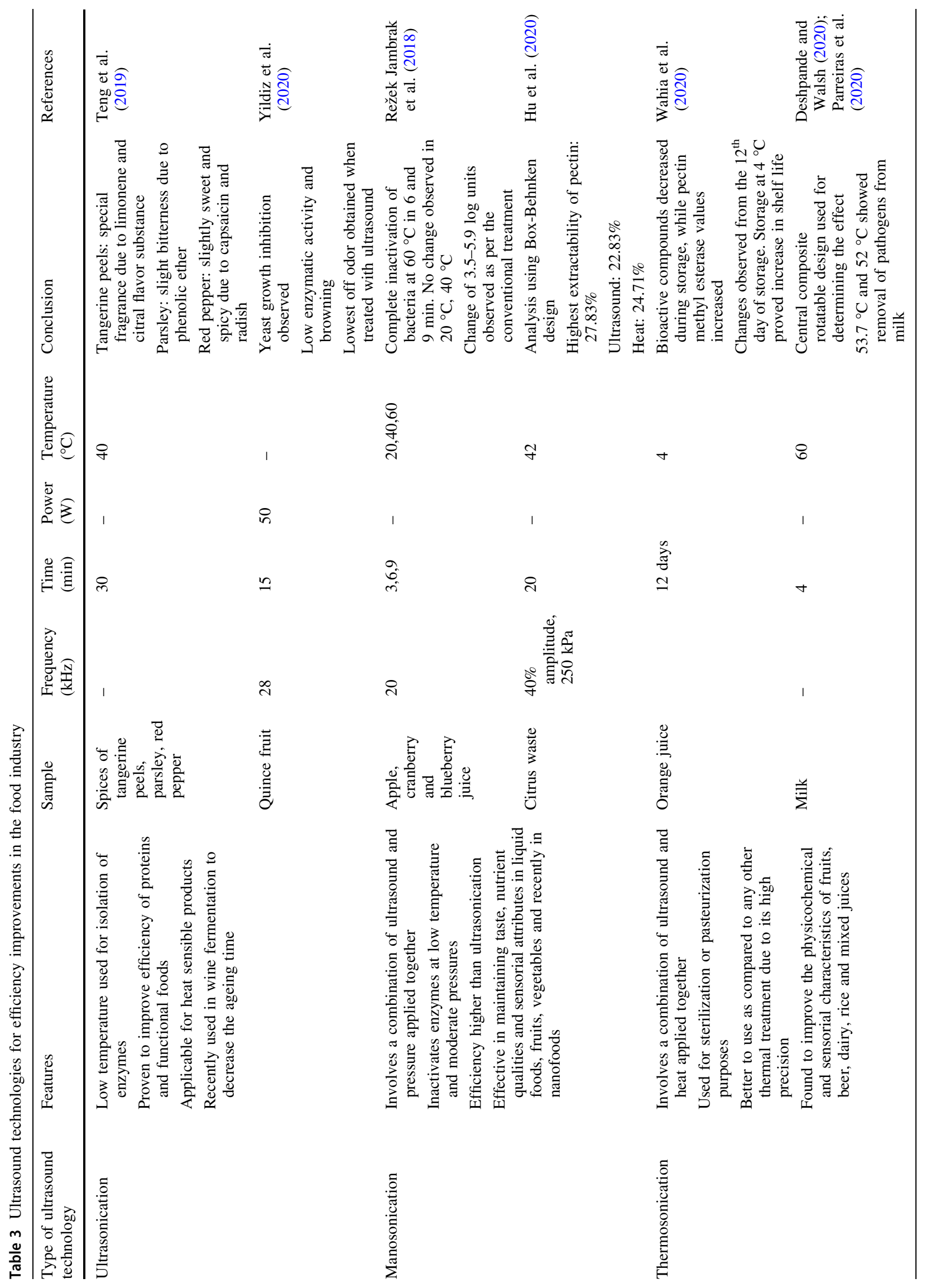




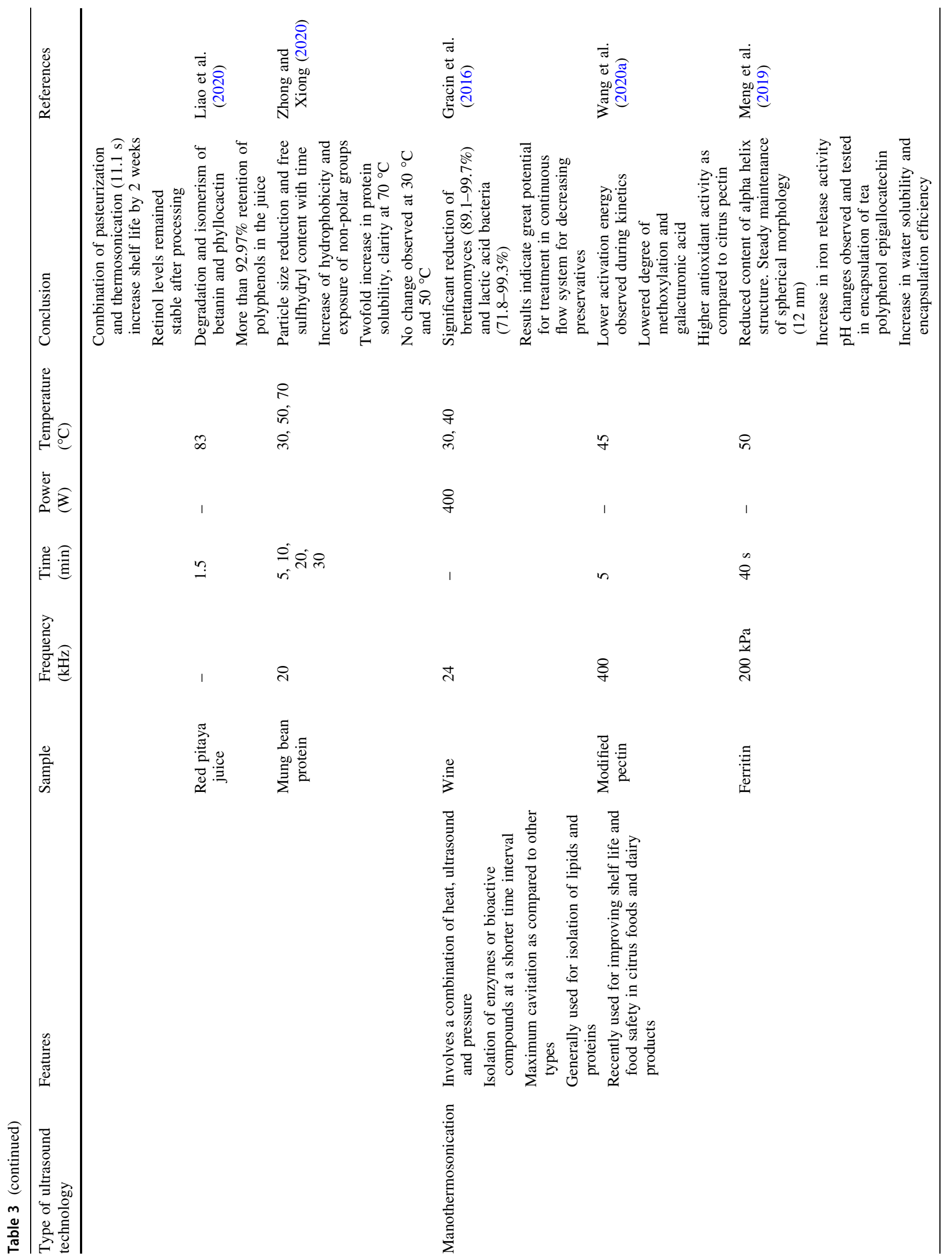


Fig. 3 Thermosonication processing generally used for treating milk and wine samples for improving the shelf life. The treatment can prove to be costeffective with reduced processing temperature due to the use of sonication as compared to conventional heat treatment or addition of synthetic preservatives

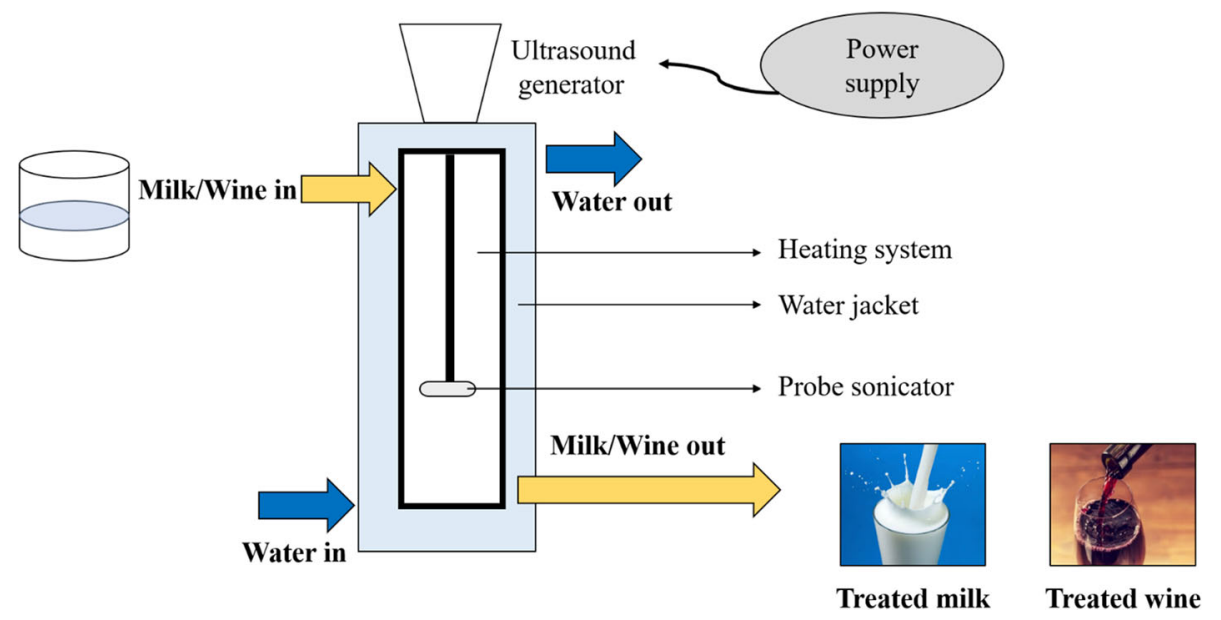

thermal pasteurization followed by filtration to get the pure beverage. A recent study reported significant reduction of about $85-90 \%$ lactic acid bacteria with high power ultrasound at $24 \mathrm{kHz}$ for $20 \mathrm{~min}$ for treatment of wine (Luo et al. 2012; Gracin et al. 2016). However, careful handling should be carried out in order to maintain the flavor and texture (Izquierdo-Cañas et al. 2020; Xiong et al. 2020).

Ultrasound studies have also found applications in isolation of bioactive compounds and processing pastes and juices in many fruits and vegetables. Recently, the technique was used to find the total phenolic content in spices like saffron (Teng et al. 2019; Azam et al. 2020; Yildiz et al. 2020). Table 4 shows the application of ultrasound technologies for various food crops. Thus, it can be concluded that ultrasound is a more sustainable technique than other traditional drying treatments.

\section{Ozone treatment}

With the growing demands of consumer slowly moving towards healthy meals and sustainable lifestyle, the demand for organic foods have increased rapidly. Consumers need a functional food that is free from additives, preservatives with a decent shelf life span. Thus, the concept of ozone treatment technology has risen in recent years. The reason for choosing ozone is due to its diverse properties and quick disintegration.

In simple words, ozone is an allotrope of oxygen. The molecule is formed when oxygen splits into a single oxygen or nascent oxygen in the presence of light or ultraviolent radiation. Ozone formation is described by chemical equations as mentioned below (Eqs. 1 and 2) (Brodowska et al. 2018).

$\mathrm{O}_{2}+e^{-} \rightarrow 2 \mathrm{O}$

$\mathrm{O}_{2}+\mathrm{O} \rightarrow \mathrm{O}_{3}$
The compound quickly decomposes into oxygen molecule and possess a high oxidation potential $(2.07 \mathrm{~V})$ making it a good antimicrobial and antiviral agent (Fisher et al. 2000; Nakamura et al. 2017) as compared to chemical preservatives like chlorine $(1.35 \mathrm{~V})$, hydrogen peroxide $(1.78 \mathrm{~V})$ and hypochlorous acid (1.79 V) (Pandiselvam et al. 2019; Afsah-Hejri et al. 2020). Apart from this, ozone removes the necessity to store harmful chemicals as the gas can be made instantly. The energy required is also minimal as compared to thermal treatment giving more importance to the shelf life (Pandiselvam et al. 2019).

Over the recent years, ozone has been listed by the Food and Drug Administration (FDA) as a generally recognized as safe (GRAS) solvent. This has led to a demanding choice in food processing and preservation sectors to ensure safety and standards in products. When in comparison with chlorine, its degradation leaves negligible residue when treated with solid foods or beverages. The technology in combination with ultrasound was also shown to enhance the bacterial safety without any damage in cabbages (Mamadou et al. 2019). Consumer grade ozone was recently proven effective in disinfecting plastic boxes for storage (Dennis et al. 2020).

Table 5 shows the effect of ozone treatment on pesticide degradation in various fruits and vegetables production. The effect of ozone treatment depends on the type of pesticide and food material, environmental conditions, time interval and the strength of pesticide. When horticulture crops were compared, tomato and lettuce had the best pesticide removal efficiency while apple and chili were the least. It was seen that the type of food matrix and structure also play a key role in preventing the growth of pathogens. Ozone can thus be considered as an advanced emerging method for multiple sectors due to its feasibility, easiness and less time consumption. 
Table 4 Ultrasound technologies for various food crops

\begin{tabular}{|c|c|c|c|c|c|c|c|}
\hline Food matrix & Method & $\begin{array}{l}\text { Frequency } \\
(\mathrm{KHz})\end{array}$ & $\begin{array}{l}\text { Time } \\
(\min )\end{array}$ & $\begin{array}{l}\text { Temperature } \\
\left({ }^{\circ} \mathrm{C}\right)\end{array}$ & $\begin{array}{l}\text { Power } \\
\text { (W) }\end{array}$ & Conclusion & References \\
\hline Onion & $\begin{array}{l}\text { Ultrasound with } \\
\text { blanching }\end{array}$ & 20 & $1,3,5$ & $\begin{array}{l}70 \text { in hot } \\
\text { water }\end{array}$ & 200 & $\begin{array}{l}\text { Retention of quercetin and other } \\
\text { bioactive compounds observed } \\
\text { Posed as a better method as } \\
\text { compared to drying treatment and } \\
\text { in terms of sustainable } \\
\text { approaches }\end{array}$ & $\begin{array}{l}\text { Ren et al. } \\
\text { (2018); Ruivo } \\
\text { Da Silva et al. } \\
\text { (2020); } \\
\text { Santiago et al. } \\
\text { (2020) }\end{array}$ \\
\hline $\begin{array}{l}\text { Tomato } \\
\text { paste } \\
\text { processing } \\
\text { waste }\end{array}$ & Ultrasound & - & $1.5-18$ & - & - & $\begin{array}{l}\text { Lycopene extraction using } \\
\text { sunflower oil }(2.18-36.8 \%) \text { as } \\
\text { green solvent } \\
87.25 \% \text { yield contrast as compared } \\
\text { to conventional organic solvents } \\
\text { (at } 70 \mathrm{~W} / \mathrm{m}^{2} \text { at } 10 \mathrm{~min} \text { ) } \\
\text { Reductions in peroxide and } \\
\text { p-anisidine values observed }\end{array}$ & $\begin{array}{l}\text { Rahimi and } \\
\text { Mikani (2019); } \\
\text { Sengar et al. } \\
\text { (2020) }\end{array}$ \\
\hline Pomegranate & $\begin{array}{l}\text { Ultra violet } \\
\text { radiation } \\
\text { sterilization and } \\
\text { ultrasound }\end{array}$ & - & $\begin{array}{l}10 \text { at } 3.5 \\
\mathrm{~L} / \mathrm{min} \\
\text { flow }\end{array}$ & 50 & 59 & $\begin{array}{l}\text { Microbial activity (at } 200 \mathrm{~W} \text { ) with } \\
\text { ultraviolet and ultrasound was } \\
\text { limited as compared to traditional } \\
\text { pasteurization process preserving } \\
\text { bioactive compounds }\end{array}$ & $\begin{array}{l}\text { Alabdali et al. } \\
(2020)\end{array}$ \\
\hline $\begin{array}{r}\text { Soursop } \\
\text { nectar }\end{array}$ & Thermosonication & 24 & 10 & 51 & - & $\begin{array}{l}\text { Inactivation of } E \text {. coli and } S \text {. aureus } \\
\text { for maintaining quality and } \\
\text { stability of nectar using acoustic } \\
\text { energy density of } 1.3-1.4 \mathrm{~W} / \mathrm{mL} \\
4.5-5 \log \text { (colony forming unit per } \\
\text { mL) reduction in pathogens } \\
\text { Inactivation of polyphenol oxidase } \\
\text { found } \\
\text { Thermosonication nectar mainly } \\
\text { contained } 85 \% \text { ascorbic acid }\end{array}$ & $\begin{array}{l}\text { (Anaya-Esparza } \\
\text { et al. 2017) }\end{array}$ \\
\hline Saffron & $\begin{array}{l}\text { Ultrasound, } \\
\text { microwave } \\
\text { assisted extraction } \\
\text { and ohmic heating } \\
\text { assisted extraction }\end{array}$ & 30 & - & - & $45-225$ & $\begin{array}{l}\text { Highest total phenolic content } \\
(928 \mathrm{mg} / 100 \mathrm{~g}) \text { was found for } \\
\text { ohmic heating assisted extraction } \\
\text { Extracts showed inhibition in lipase } \\
\text { enzyme } \\
\text { Presence of kaempferol and } \\
\text { anthocyanins found in all extracts }\end{array}$ & $\begin{array}{l}\text { Sarfarazi et al. } \\
\text { (2020); } \\
\text { Hashemi et al. } \\
(2020)\end{array}$ \\
\hline
\end{tabular}

\section{Pulse electric field}

Pulse electric field technology is an advanced pre drying treatment involving shorter residence time for treatment of foods. The method was widely recognized due to its continuous operation and low requirement of electric fields $(1-5 \mathrm{kV} / \mathrm{cm})$. The method could be considered as a substitute for thermal drying and could enhance the food drying as it requires a very low temperature of $40{ }^{\circ} \mathrm{C}$ for functioning (Barba et al. 2015; Wiktor et al. 2016). Figure 4 shows the representative diagram of the process involved in treatment of liquid foods and paste using pulse electric field.
The methodology of pulse electric field involves placing the food (fruit, vegetable, milk or any juices) between two electrodes after which a pulse is applied with high voltage $(50 \mathrm{kV} / \mathrm{cm})$ for short time intervals. The principle is a combination of electroporation and electropermeabilization (Barba et al. 2015). The electric field breaks the cell membrane matrix of the food thus enhancing the nutritive qualities, safety and increasing shelf life. The factors affecting pulse electric field involve field strength, pulse width, frequency, treatment time, polarity and temperature used (Odriozola-Serrano et al. 2013; Wiktor et al. 2016).

Over the years, demand for pulse electric field has grown drastically in all food sector areas. It can be used for destruction of bacteria ( $E$ coli) in milk. The treated milk 
Table 5 Effect of ozone treatment on pesticide degradation in horticulture production

\begin{tabular}{|c|c|c|c|c|c|}
\hline $\begin{array}{l}\text { Food } \\
\text { material }\end{array}$ & Type of pesticide & Concentration of pesticide & $\begin{array}{l}\text { Time kept under } \\
\text { ozone (min) }\end{array}$ & $\begin{array}{l}\text { Level of } \\
\text { reduction }(\%)\end{array}$ & References \\
\hline $\begin{array}{l}\text { Apple } \\
\text { fruit }\end{array}$ & Boscalid & $3 \mathrm{ppm}$ in ozonized water & $15-20$ & 42 & Sadło et al. (2017) \\
\hline Cabbages & Chlorothalonil & $250 \mathrm{mg} / \mathrm{h}$ ozone gas & 15 & 77 & Chen et al. (2013) \\
\hline Carrots & Difenoconazole & $5 \mathrm{mg} / \mathrm{L}$ ozone gas & $10-15$ & 95.3 & Souza et al. (2018) \\
\hline Chili & Chlorpyrifos & $\begin{array}{l}\text { Ozone fumigation with constant flow rate } \\
\text { of } 5.5 \mathrm{~g} / \mathrm{h}\end{array}$ & 30 & 68 & $\begin{array}{l}\text { Sintuya et al. } \\
\text { (2018) }\end{array}$ \\
\hline Lettuce & Chlorpyrifos & 5 ppm ozone gas & 15 & 97.15 & Wu et al. (2019) \\
\hline Spinach & $\begin{array}{l}\text { Chlorpyrifos } \\
\text { Acetamiprid }\end{array}$ & Ozone wash with water $(0.4 \mathrm{mg} / \mathrm{L})$ & 30 & 53 & Wu et al. (2019) \\
\hline Tomato & Fenitrothion & $\begin{array}{l}\text { Ozone wash with water }(2 \mathrm{ppm}) \text { in a } \\
\text { microbubble format }\end{array}$ & 20 & 98.32 & $\begin{array}{l}\text { Pandiselvam et al. } \\
\text { (2020) }\end{array}$ \\
\hline
\end{tabular}

Fig. 4 Application of pulse electric field generally used for treating liquid foods and pastes. The technique is a nonthermal food preservation method involving usage of pulses of electricity into the food material. The treatment gives high quality food with almost no change in texture or quality thus maintaining the original taste of food

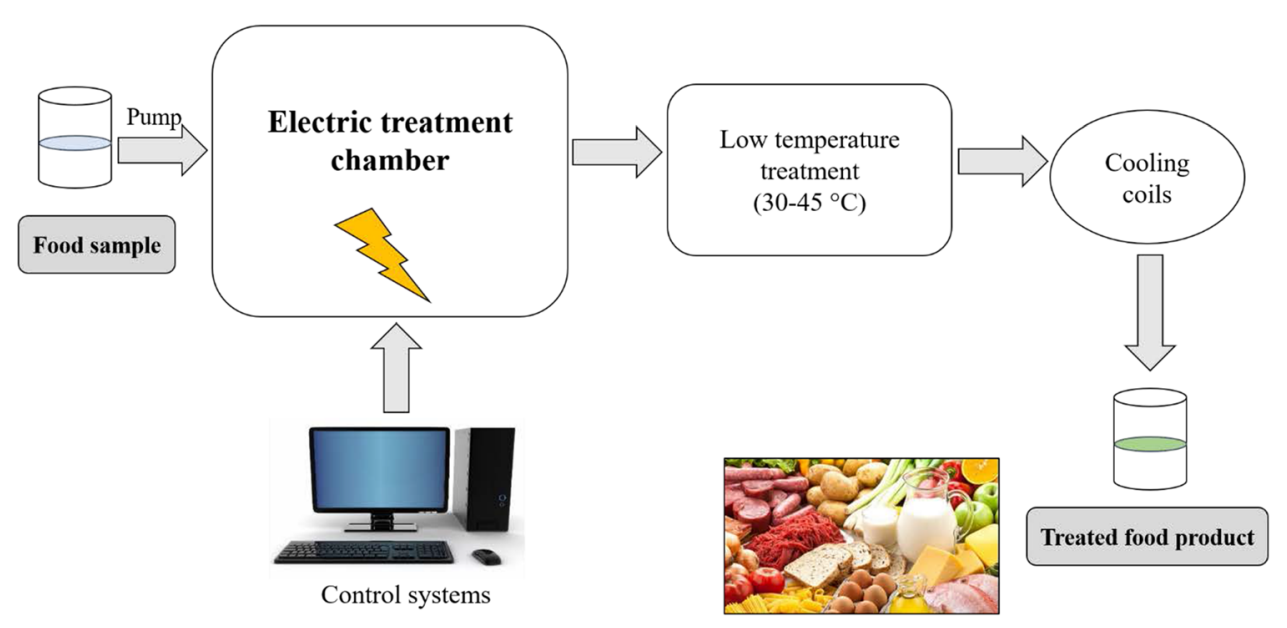

was found to be high in quality and possessed an increased shelf life. A recent investigation was also carried out on watermelon and citrus juices which showed changes in physicochemical and antimicrobial properties (Aghajanzadeh and Ziaiifar 2018; Bhattacharjee et al. 2019). Table 6 summarizes the outcomes of application of pulse electric field treatment on various food materials.

\section{Nanotechnology for food preservation}

Nanotechnology has become a huge breakthrough with great potential to promote sustainability. It integrates branches of applied sciences such as physics, biology, food technology, environmental engineering, medicine and materials processing. In simple terms, nanotechnology involves any material or nanoparticle having one or more dimensions to the order $100 \mathrm{~nm}$ or less (Auffan et al. 2009; He et al. 2019). The technology is preferred as they possess different properties like slow release action, target specific nature, precise action on active sites and high surface area (Joshi et al. 2019). The reason for the success of nanotechnology is due to its promising results, no pollutant release, energy efficient and less space requirements. Apart from these success factors, nanotechnology has also shown versatile applications in terms of safety, toxicity and risk assessment in areas of agriculture, food and environment (Kaphle et al. 2018). Figure 5 shows the different avenues of nanotechnology development in the food sector.

Nanomaterials are broadly classified into two types, namely organic and inorganic, depending on their nature and functionalities (Table 7).

Nanotechnology has been regarded as a promising tool for growing the economy in near future as well as maintaining the plant growth and nutritional qualities of the food commodity. Use of nanofertilizers and precision farming has posed several benefits in weed control and decrease in chemical pesticide thus enhancing shelf life. Growing use of nanotechnology in agro-food system industry may even pose as a solution to solve challenges in 
Table 6 Effect of pulse electric field treatment on food materials

\begin{tabular}{|c|c|c|c|}
\hline $\begin{array}{l}\text { Food } \\
\text { material }\end{array}$ & Process conditions & Outcomes & References \\
\hline Blueberries & $\begin{array}{l}2 \mathrm{kV} / \mathrm{cm}, 30 \mu \mathrm{s} \text { for } 4-6 \mathrm{~h} \\
\text { at } 40{ }^{\circ} \mathrm{C}, 60{ }^{\circ} \mathrm{C}, 75{ }^{\circ} \mathrm{C}\end{array}$ & $\begin{array}{l}\text { Least impact on the nutritive qualities post-treatment till } \\
75^{\circ} \mathrm{C} \\
\text { Process saved the drying time by } 2-30 \mathrm{~h}\end{array}$ & Yu et al. (2017) \\
\hline $\begin{array}{l}\text { Date palm } \\
\text { fruit }\end{array}$ & $1,2,3 \mathrm{kV} / \mathrm{cm}, 30$ pulses, $100 \mu \mathrm{s}$ & $\begin{array}{l}\text { Positive impact and increase in carotenoids, } \\
\text { anthocyanins, flavonoids and phenolic } \\
\text { Increase in the volatile and bioactive compounds at } \\
3 \mathrm{kV} / \mathrm{cm} \\
\text { Better feasibility as compared to solvent extraction }\end{array}$ & $\begin{array}{l}\text { Yeom et al. (2004); Siddeeg } \\
\text { et al. (2019) }\end{array}$ \\
\hline $\begin{array}{l}\text { Apple } \\
\text { juice }\end{array}$ & $\begin{array}{l}12.5 \mathrm{kV} / \mathrm{cm}, 27.6 \mathrm{~L} / \mathrm{h} \text { flow at } 76.4 \mathrm{~kJ} \\
72{ }^{\circ} \mathrm{C} \text { for } 15 \mathrm{~s} \\
85{ }^{\circ} \mathrm{C} \text { for } 30 \mathrm{~s}\end{array}$ & $\begin{array}{l}\text { Huge variations in peroxidase activities and change in } \\
\text { polyphenol oxidase }\end{array}$ & $\begin{array}{l}\text { Wibowo et al. (2019); Salehi } \\
\text { (2020) }\end{array}$ \\
\hline Red beet & $2-6 \mathrm{kV} / \mathrm{cm}, 10-80 \mu \mathrm{s}$ & $\begin{array}{l}\text { Betanin concentration in red beet increased by } 6.7-7.2 \\
\text { times post-treatment }\end{array}$ & Luengo et al. (2016) \\
\hline Olive paste & $\begin{array}{l}16 \mathrm{kV}, 145 \mathrm{~A}, 30^{\circ} \mathrm{C}, 200 \mu \mathrm{s}, 75 \mathrm{~Hz} \\
30 \mathrm{~min}\end{array}$ & $\begin{array}{l}\text { Extractability increase from } 79.5 \% \text { to } 85.5 \% \\
\text { Enhancement of elenolic acid and tyrosol } \\
\text { Overall olive oil extraction and quality found }\end{array}$ & Tamborrino et al. (2020) \\
\hline $\begin{array}{l}\text { Clover } \\
\text { sprouts }\end{array}$ & $\begin{array}{l}1,2.5,5 \mathrm{kV} / \mathrm{cm}, 21{ }^{\circ} \mathrm{C} \text { and } 80 \% \\
\text { humidity, } 12 \mathrm{~h} \text { for } 7 \text { days }\end{array}$ & $\begin{array}{l}\text { Dominant carotenoid was lutein during light exposure } \\
\text { Increase of } 6-8 \% \text { beta-carotene found in red clovers } \\
\text { Decrease of } 3.3 \% \text { zeaxanthin observed }\end{array}$ & $\begin{array}{l}\text { Gałązka-Czarnecka et al. } \\
\text { (2020) }\end{array}$ \\
\hline
\end{tabular}
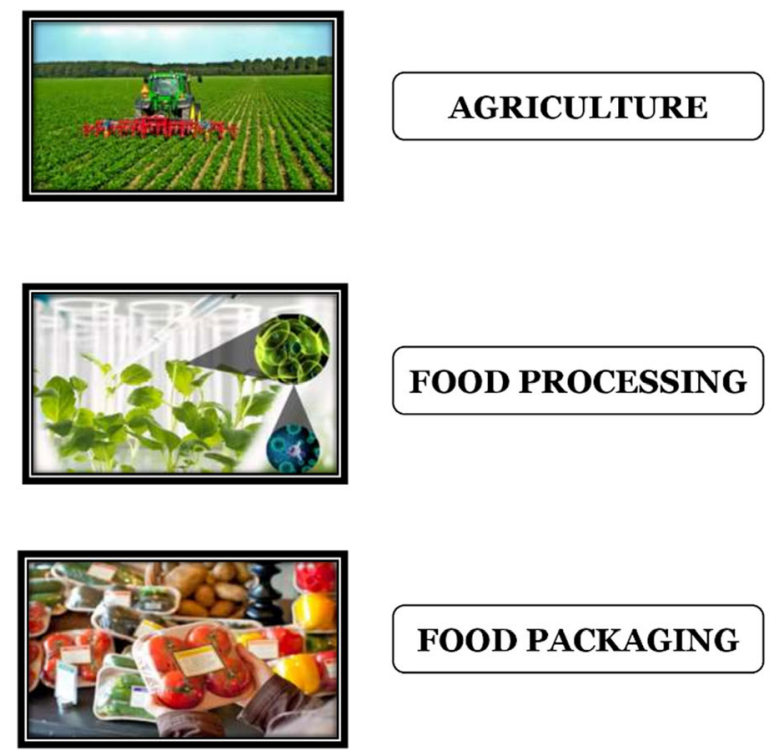

\section{FOOD PACKAGING}

Fig. 5 Applications for nanotechnology in agriculture, food processing and packaging. Nanotechnology has gained a lot of interest with versatile applications and unique properties enabling efficient

food security and agriculture (Yata et al. 2018; Ghouri et al. 2020). The three primary avenues where the technology could grow include food processing, agriculture and packaging.
Nanosensors Nanomaterials

$\begin{array}{ll}\text { - Precision } & -\mathrm{nTiO}_{2} \\ \text { agriculture } & \cdot \mathrm{Gold} / \text { Silver Nanoparticles }\end{array}$

- Chitosan

- Nano formulated agrochemicals

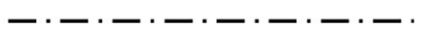

Sensorial attributes Nutrient delivery

- Nanocapsules for - Targeted nutrient delivery flavor enhancement to plants

- Detection of enzymesubstrate interactions

Smart packaging

- Detection

- Sensors

\section{Active packaging}

- Antimicrobials

- $\mathrm{TiO}_{2}, \mathrm{SiO}_{2}$ and Chitosan based additives

processes and quality products. The use of nanomaterials, nanosensors, precision agriculture and advanced packaging can play a promising role in improving the food sector

\section{Nanotechnology in food processing}

The concept of nanotechnology has paved the way in processing and formulation of colorants, sensors, flavors, additives, preservatives and food supplements (nanoencapsulation and nanoemulsion) in both animal and plant 
Table 7 Types and functionalities of nanomaterials

\begin{tabular}{|c|c|c|c|c|}
\hline Category & Nanomaterial & Use of nanomaterial & Application in foods & References \\
\hline \multirow[t]{5}{*}{$\begin{array}{l}\text { Inorganic } \\
\text { nanoparticles }\end{array}$} & $\begin{array}{l}\text { Silver } \\
\text { nanoparticles }\end{array}$ & $\begin{array}{l}\text { Generally used as antimicrobial agents in food } \\
\text { packaging and storage containers } \\
\text { Recently used as a stabilizing agent in nanofillers }\end{array}$ & $\begin{array}{l}\text { Effective food } \\
\text { packaging solution } \\
\text { preventing entry of } \\
\text { pathogens } \\
\text { Crop yield variations } \\
\text { seen in chili, radish, } \\
\text { lettuce }\end{array}$ & $\begin{array}{l}\text { Li et al. (2020); } \\
\text { Zorraquín-Peña et al. } \\
\text { (2020); Seray et al. } \\
(2020)\end{array}$ \\
\hline & $\begin{array}{l}\mathrm{ZnO} \\
\text { nanoparticles }\end{array}$ & $\begin{array}{l}\text { Considered a biocompatible material } \\
\text { Nanomaterial found positive in control of food borne } \\
\text { pathogens }\end{array}$ & $\begin{array}{l}\text { Increase in quality of } \\
\text { cucumber by } 36 \% \\
\text { Carotene, zinc and iron } \\
\text { increase in cucumber } \\
\text { observed }\end{array}$ & $\begin{array}{l}\text { (Venkatasubbu et al. } \\
\text { 2016; Seray et al. } \\
\text { 2020) }\end{array}$ \\
\hline & $\begin{array}{l}\mathrm{Se} \\
\text { nanoparticles }\end{array}$ & $\begin{array}{l}\text { Combination of } \mathrm{Cu}+\mathrm{Se} \text { nanoparticles increased the } \\
\text { overall yield and chlorophyll content of tomato }\end{array}$ & $\begin{array}{l}\text { Modification in the } \\
\text { enzymatic activity of } \\
\text { tomato plant } \\
\text { Tomato yield increased } \\
\text { by } 21 \% \text { with } 10 \mathrm{mg} / \mathrm{L} \\
\text { Se nanoparticles }\end{array}$ & $\begin{array}{l}\text { (Hernández-Hernández } \\
\text { et al. 2019) }\end{array}$ \\
\hline & $\begin{array}{l}\mathrm{TiO}_{2} \\
\text { nanoparticles }\end{array}$ & $\begin{array}{l}\text { Photo activities shown on food contact surfaces } \\
\text { Dual usage found in cosmetic (in sunscreens) }\end{array}$ & $\begin{array}{l}\text { Packaging film of } \mathrm{TiO}_{2} \\
\text { proved better for } \\
\text { storage of green } \\
\text { lettuce }\end{array}$ & $\begin{array}{l}\text { (Weir et al. 2012; Peter } \\
\text { et al. 2015; } \\
\text { Yemmireddy and Hung } \\
\text { 2015) }\end{array}$ \\
\hline & $\begin{array}{l}\mathrm{SiO}_{2} \\
\quad \text { nanoparticles }\end{array}$ & $\begin{array}{l}\text { Anti-caking agent in certain powdered foods } \\
\text { Abiotic stress resistant in plants and crops }\end{array}$ & $\begin{array}{l}\text { Reduced the } \\
\text { development stages of } \\
\text { grapes (dosage: } 0.5 \mathrm{~g} / \\
\text { L) }\end{array}$ & $\begin{array}{l}\text { Lim et al. (2015); Zahedi } \\
\text { et al. (2020) }\end{array}$ \\
\hline \multirow[t]{3}{*}{$\begin{array}{l}\text { Organic } \\
\text { nanoparticles }\end{array}$} & $\begin{array}{l}\text { Lipid } \\
\text { nanoparticles }\end{array}$ & $\begin{array}{l}\text { Used as oral delivery systems in drugs and active } \\
\text { ingredients }\end{array}$ & $\begin{array}{l}\text { Nutraceutical and drug } \\
\text { delivery systems }\end{array}$ & $\begin{array}{l}\text { Severino et al. (2012); } \\
\text { Ban et al. (2020); } \\
\text { Paliwal et al. (2020) }\end{array}$ \\
\hline & $\begin{array}{l}\text { Protein } \\
\text { nanoparticles }\end{array}$ & $\begin{array}{l}\text { Great potential in catalysis, synthesis, bio imaging } \\
\text { Found in foods in the form of casein }\end{array}$ & $\begin{array}{l}\text { Bovine milk and other } \\
\text { dairy foods }\end{array}$ & Samadarsi et al. (2020) \\
\hline & $\begin{array}{l}\text { Carbohydrate } \\
\text { nanoparticles }\end{array}$ & $\begin{array}{l}\text { They are digestible or indigestible polysaccharides } \\
\text { like sodium, alginate, pectin and cellulose. } \\
\text { Physicochemical stability and solubility over algal } \\
\text { oil nanoparticles showing high efficiency of } 98.57 \% \\
\text { in the system }\end{array}$ & Encapsulation of oil & $\begin{array}{l}\text { Verma et al. }(2020) \text {; } \\
\text { Wang et al. (2020b) }\end{array}$ \\
\hline
\end{tabular}

based products (He et al. 2019). The diversity of nanotechnology in various fields has led to introduction of nanosensors in food processing industries. Nanomaterials have shown several electrochemical and optical properties in different sauces, beverages, oils and juices. Table 8 shows the different nanomaterials used as sensors in food industry.

Distinctive characteristics have shown great qualities in the area of food processing as ingredients and supplements. Oxide chemicals such as magnesium oxide and silicon dioxide can act as a food flavor, food color and a baking agent. The use of titanium dioxide has also been certified as an additive in gums, sauces and cakes (Weir et al. 2012). Additionally, copper oxide, iron oxide and zinc oxide have been categorized as GRAS materials by European Food
Safety Authority (EFSA) for animal and plant products (He et al. 2019).

\section{Nanotechnology in agriculture}

The use of nanotechnology in agriculture and the concept of precision agriculture has gained a lot of interest in the recent years. The main goal of agriculture is to reduce the volume of chemicals, minimize nutrient losses and increase the overall performance of crops. Although chemical fertilizers are added for increasing the crop yields, it pollutes and harms the soil, water, food and environment (Riah et al. 2014). Precision agriculture is one of the green ways to tackle this issue. It is a system based on artificial intelligence that understands crop quality, soil quality and 
Table 8 Use of nanomaterials as sensors in the food industry

\begin{tabular}{|c|c|c|c|c|c|}
\hline $\begin{array}{l}\text { Food sensor } \\
\text { type }\end{array}$ & Material Detection & $\begin{array}{l}\text { Sample } \\
\text { chosen }\end{array}$ & Nanomaterial & Functions and outcomes & References \\
\hline \multirow[t]{8}{*}{ Electrochemical } & $\begin{array}{l}\text { Tert- } \\
\text { butylhydroquinine }\end{array}$ & $\begin{array}{l}\text { Edible oils in } \\
\text { bakery } \\
\text { industry }\end{array}$ & $\begin{array}{l}\text { Au nanoparticles } \\
\text { electrodeposited on } \\
\text { graphene ribbons }\end{array}$ & $\begin{array}{l}\text { Conductivity improvements due to } \\
\text { increase in surface area on the } \\
\text { target sites }\end{array}$ & Delfino et al. (2020) \\
\hline & Antioxidants & $\begin{array}{l}\text { Mixed fruit } \\
\text { juices }\end{array}$ & Graphene nanoribbons & $\begin{array}{l}\text { Enhanced surface and } \\
\text { electrochemical properties seen }\end{array}$ & Ye et al. (2020) \\
\hline & $\begin{array}{l}\text { Glucose, sucrose } \\
\text { and toxins }\end{array}$ & Soft drinks & $\begin{array}{l}\text { Cu nanoparticles based } \\
\text { inks }\end{array}$ & Carbohydrate oxidation & $\begin{array}{l}\text { Pradela-Filho et al. } \\
\text { (2020) }\end{array}$ \\
\hline & Melamine & Milk & Carbon nanoparticles & $\begin{array}{l}\text { Conductive and functional layer for } \\
\text { detection of Salmonella strains }\end{array}$ & Nguyen et al. (2020) \\
\hline & Adulterants & Chili sauce & $\mathrm{Pd} / \mathrm{Au}$ nanocrystals & $\begin{array}{l}\text { Enhanced catalytic activity and } \\
\text { high surface area }\end{array}$ & Zou et al. (2020) \\
\hline & Residual pesticides & $\begin{array}{l}\text { Potato, onion } \\
\text { and } \\
\text { cabbage }\end{array}$ & $\mathrm{TiO}_{2} / \mathrm{Pd}$ nanostructure & $\begin{array}{l}\text { Improved electrochemical } \\
\text { properties and conductivity }\end{array}$ & $\begin{array}{l}\text { Naser-Sadrabadi } \\
\text { et al. }(2020)\end{array}$ \\
\hline & $\begin{array}{l}\text { Pathogens } \\
\text { (Salmonella } \\
\text { species) }\end{array}$ & $\begin{array}{l}\text { Skimmed } \\
\text { milk }\end{array}$ & Au Nanoparticles & $\begin{array}{l}\text { Electrochemical generation of } \\
\text { signals }\end{array}$ & $\begin{array}{l}\text { Echegoyen et al. } \\
\text { (2016); Nguyen } \\
\text { et al. (2020) }\end{array}$ \\
\hline & $\begin{array}{l}\text { Heavy metals } \\
(\mathrm{Hg}+)\end{array}$ & Water & Au Nanoparticles & $\begin{array}{l}\text { Higher surface area for thiophenol } \\
\text { modified species }\end{array}$ & Tian et al. (2020) \\
\hline \multirow[t]{3}{*}{ Optical } & Mycotoxins & Milk & $\mathrm{CeO}_{2}$ nanoparticles & Catalytic activity & Goud et al. (2020) \\
\hline & Gallic acid & $\begin{array}{l}\text { Clove and } \\
\text { green tea } \\
\text { extracts }\end{array}$ & $\begin{array}{l}\text { Au nanotubes bismuth } \\
\text { based }\end{array}$ & $\begin{array}{l}\text { Physical and morphological } \\
\text { changes }\end{array}$ & $\begin{array}{l}\text { Madhusudhana et al. } \\
\text { (2020) }\end{array}$ \\
\hline & $\begin{array}{l}\text { Antibiotics } \\
\text { (Sulfonamides) }\end{array}$ & Honey & Au nanoparticles & $\begin{array}{l}\text { Surface plasmon resonance } \\
\text { properties }\end{array}$ & Ye et al. (2020) \\
\hline
\end{tabular}

detects weed controls generally through drones. The area has recently gained interest in nutritional management and various optical properties to address food wastage and to feed the growing population (Duhan et al. 2017). Majority of plant species (cereal grains like wheat, rice, barley, tobacco, soybean, rye) follow the biophysical process of photosynthetically active radiation and electron transport. These targets have been identified to improve photosynthesis activity.

There has been many discussions and investigation on the concept of plant nanobionics and photosynthesis. Plant nanobionics deals with appropriate insertion of nanoparticles into the chloroplast of the plant cell for improving the plant productivity. It has been proven that titanium dioxide nanoparticles $\left(\mathrm{nTiO}_{2}\right)$ have become the "go-to" nanoparticles for efficient photosynthesis process (Hong et al. 2005; Gao et al. 2006, 2008). The application of $\mathrm{nTiO}_{2}$ with spinach and tomato leaves under mild heat stress improved the overall photosynthesis process showing significant improvement in the transpiration and conductance rates (Gao et al. 2008; Qi et al. 2013).

Nanomaterials like silver ions, polymeric compounds and gold nanoparticles are also being investigated for use in pesticides. Usage of gold and silver nanoparticles has also had a positive effect to restrict the pest and improve plant growth (Ndlovu et al. 2020). Studies have also investigated on sulfur-based nanoparticle $(35 \mathrm{~nm})$ for organic farming which prevent fungal growth from apple tomatoes and grapes (Joshi et al. 2019).

\section{Nanotechnology in food packaging}

Many fresh fruits and vegetables are sensitive to oxygen, water permeability and ethylene leading to deterioration of food quality (Gaikwad et al. 2018, 2020). Thus, food packaging plays a critical role in addressing this issue. Nanoparticles and polymer-based composites have proven to be the best solutions (Auffan et al. 2009; Joshi et al. 2019). The application of a natural polymer or a biopolymer and coating it on the food surface has recently shown promise in preserving foods (Luo et al. 2020). Table 9 shows the different applications of nanomaterials used in food packaging. Although the application of nanomaterials in smart packaging is in its early stage, rapid advancements have been carried out through the years as it offers safe and sustainable approach (Rai et al. 2019). 
Table 9 Applications of nanomaterials in food packaging

\begin{tabular}{lllll}
\hline Nanomaterial & Packaging material & Food samples & Application of nanomaterial & References \\
\hline $\mathrm{Ag}$ & Cellulose films & Tomatoes & Antibacterial properties & Gu et al. (2020) \\
$\mathrm{TiO}_{2}$ & Chitosan & Grapes & Preservative possessing antimicrobial activity & Zhang et al. (2017) \\
$\mathrm{TiO}_{2}$ & Polyacrylonitrile & Tomatoes & Ethylene scavenging property & Zhu et al. (2019b) \\
$\mathrm{ZnO}$ & Chitosan & Black grape, apple, mango, tomato & Antioxidant and antibacterial properties & Yadav et al. (2021) \\
\hline
\end{tabular}

The usage of chitosan and chitosan-based additives and films has been recently explored with multiple functionalities with positive outcomes. Chitosan-based films, in general, possess antioxidant, antimicrobial and antifungal properties making it a good replacement for synthetic chemicals (Yuan et al. 2016; Yousuf et al. 2018). The use of chitosan-based derivatives offer a promising solution towards maintaining the shelf life of foods without disturbing its sensorial properties (Kulawik et al. 2020). A recent study proved that chitosan-based matrices can also be used for clarification, preservation and encapsulation of different beverages (alcoholic, non-alcoholic as well as dairy based), fruit juices, tea and coffee (Morin-Crini et al. 2019). Apart from this, nanocomposites (combination of different nanomaterials) have shown efficient thermal and barrier properties at a low cost. Researchers evaluated the concept of the nanocomposites membranes and concluded that it decreased the water permeability in foods by a value of 46 (Jose et al. 2014). An increase in corrosion resistance was evaluated with use of clay and epoxy composites (Gabr et al. 2015).

Edible coatings with nanomaterials have also shown increasing potential towards food storage of fruits and vegetables. These coatings hold useful while transportation from factory to retailers and also maintain the nutritional qualities without causing any physical damage. Edible coatings are generally prepared from fats, proteins and polysaccharides which have been shown to block gases. Nanoclays and nanolaminates have also shown promising results to improve their barrier properties to gases for efficient food packaging (Echegoyen et al. 2016). Nanolaminates involve layer-by-layer deposition of a special coating where the charged surface is applied on food. The application of carbon nanotubes as nanofillers in gelatin films has also been successfully demonstrated (Rai et al. 2019). The biofilms are found to have improved tensile strength, mechanical, thermal and antimicrobial properties (Jamróz et al. 2020; Zubair and Ullah 2020). Thus, nanomaterials have emerged as an integral part while addressing nanotechnology in food packaging.

\section{Conclusion}

With tons of foods being wasted every single day, food preservation has been the need of the hour for extending the shelf life to help feed millions of people globally. Although plenty of advanced technologies have been introduced, major strides need to be taken to have a sustainable food system. Availability, access and proper utilization of food should be well balanced in order to understand the value of food security. It is important to maintain a correct and precise balance of technology with respect to design and cost effectiveness. Constant investigation is also being carried out in the area of finding more natural preservatives with excellent antioxidant and antimicrobial properties as they are safe to consume and eliminate processed food. The concept of hurdle technology, which combines multiple techniques to measure different variables like temperature, water activity, $\mathrm{pH}$, moisture content and enzyme activities has also been explored to meet the consumer demands for an efficient food system. Another growing solution is in the area of nanotechnology in foods which has been discussed in this article. However, research on different nanomaterials, its toxicity, its safety to consumers and genetic factors is still under debates and discussions. The concept of bioencapsulation and nanoencapsulation in food supplements and drug developments is also growing at a fast pace keeping in mind the health and environmental effects. Further work needs to be done in data visualization and artificial intelligence, internet of things and machine learning. This would help changing the food and agricultural industry in the area of functional foods and crops through digitalization.

Acknowledgement The authors are thankful to Sivaraman Prabhakar for insightful discussions.

Funding This research did not receive any specific grant from funding agencies in the public, commercial or not-for-profit sectors. 


\section{References}

Afsah-Hejri L, Hajeb P, Ehsani RJ (2020) Application of ozone for degradation of mycotoxins in food: a review. Compr Rev Food Sci Food Saf 19:1777-1808. https://doi.org/10.1111/1541-4337. 12594

Aghajanzadeh S, Ziaiifar AM (2018) A review of pectin methylesterase inactivation in citrus juice during pasteurization. Trends Food Sci Technol 71:1-12. https://doi.org/10.1016/j.tifs.2017. 10.013

Alabdali TAM, Icyer NC, Ozkaya GU, Durak MZ (2020) Effect of stand-alone and combined ultraviolet and ultrasound treatments on physicochemical and microbial characteristics of pomegranate juice. Appl Sci 10:5458. https://doi.org/10.3390/ app 10165458

Anaya-Esparza LM, Velázquez-Estrada RM, Sayago-Ayerdi SG et al (2017) Effect of thermosonication on polyphenol oxidase inactivation and quality parameters of soursop nectar. LWT 75:545-551. https://doi.org/10.1016/j.lwt.2016.10.002

Auffan M, Rose J, Bottero JY et al (2009) Towards a definition of inorganic nanoparticles from an environmental, health and safety perspective. Nat Nanotechnol 4:634-641. https://doi.org/10. 1038/nnano.2009.242

Azam SMR, Ma H, Xu B et al (2020) Efficacy of ultrasound treatment in the removal of pesticide residues from fresh vegetables: a review. Trends Food Sci Technol 97:417-432. https://doi.org/10. 1016/j.tifs.2020.01.028

Ban C, Jo M, Park YH et al (2020) Enhancing the oral bioavailability of curcumin using solid lipid nanoparticles. Food Chem 302:125328. https://doi.org/10.1016/j.foodchem.2019.125328

Barba FJ, Parniakov O, Pereira SA et al (2015) Current applications and new opportunities for the use of pulsed electric fields in food science and industry. Food Res Int 77:773-798. https://doi.org/ 10.1016/j.foodres.2015.09.015

Barbosa de Lima WCP, Nascimento LPC, Lima Dantas R et al (2020) Heat transfer in the cooling, freezing and post-freezing of liquid food: modeling and simulation. Diffus Found 25:37-53. https:// doi.org/10.4028/www.scientific.net/df.25.37

Bazhal M, Lebovka N, Vorobiev E (2003) Optimisation of pulsed electric field strength for electroplasmolysis of vegetable tissues. Biosyst Eng 86:339-345. https://doi.org/10.1016/S15375110(03)00139-9

Bermúdez-Aguirre D, Corradini MG, Mawson R, Barbosa-Cánovas GV (2009) Modeling the inactivation of Listeria innocua in raw whole milk treated under thermo-sonication. Innov Food Sci Emerg Technol 10:172-178. https://doi.org/10.1016/j.ifset.2008. 11.005

Bhattacharjee C, Saxena VK, Dutta S (2019) Novel thermal and nonthermal processing of watermelon juice. Trends Food Sci Technol 93:234-243. https://doi.org/10.1016/j.tifs.2019.09.015

Bhattacharyya SK (2020) Pal S (2020) Measurement of parboiled and non-parboiled rice grain dimension during hydro thermal treatment using image processing. Natl Conf Emerg Trends Sustain Technol Eng Appl NCETSTEA 2020:8-12. https://doi. org/10.1109/NCETSTEA48365.2020.9119920

Białkowska A, Majewska E, Olczak A, Twarda-clapa A (2020) Ice binding proteins: diverse biological roles and applications in different types of industry. Biomolecules 10:274. https://doi.org/ 10.3390/biom10020274

Brandão VAA, Araújo de Queiroz R, Lima Dantas R et al (2020) Cooling and freezing of cashew apple using computational fluid dynamics. Diffus Found 25:114-132. https://doi.org/10.4028/ www.scientific.net/df.25.114

Bräutigam KR, Jörissen J, Priefer C (2014) The extent of food waste generation across EU-27: different calculation methods and the reliability of their results. Waste Manag Res 32:683-694. https:// doi.org/10.1177/0734242X14545374

Brodowska AJ, Nowak A, Śmigielski K (2018) Ozone in the food industry: principles of ozone treatment, mechanisms of action, and applications: an overview. Crit Rev Food Sci Nutr 58:2176-2201. https://doi.org/10.1080/10408398.2017.1308313

Butnaru E, Stoleru E, Brebu MA et al (2019) Chitosan-based bionanocomposite films prepared by emulsion technique for food preservation. Materials (Basel) 12:1-17. https://doi.org/10.3390/ ma12030373

Cañumir JA, Celis JE, De Bruijn J, Vidal LV (2002) Pasteurisation of apple juice by using microwaves. LWT - Food Sci Technol 35:389-392. https://doi.org/10.1006/fstl.2001.0865

Cares MG, Vargas Y, Gaete L et al (2010) Ultrasonically assisted extraction of bioactive principles from Quillaja Saponaria Molina. Phys Procedia 3:169-178. https://doi.org/10.1016/j. phpro.2010.01.024

Charles-Rodríguez AV, Nevárez-Moorillón GV, Zhang QH, OrtegaRivas E (2007) Comparison of thermal processing and pulsed electric fields treatment in pasteurization of apple juice. Food Bioprod Process 85:93-97. https://doi.org/10.1205/fbp06045

Chen JY, Lin YJ, Kuo WC (2013) Pesticide residue removal from vegetables by ozonation. J Food Eng 114:404-411. https://doi. org/10.1016/j.jfoodeng.2012.08.033

Cheng L, Sun DW, Zhu Z, Zhang Z (2017) Emerging techniques for assisting and accelerating food freezing processes: a review of recent research progresses. Crit Rev Food Sci Nutr 57:769-781. https://doi.org/10.1080/10408398.2015.1004569

Christiansen MV, Pedersen TB, Brønd JN et al (2020) Physical properties and storage stability of reverse osmosis skim milk concentrates: effects of skim milk pasteurisation, solid content and thermal treatment. J Food Eng 278:109922. https://doi.org/ 10.1016/j.jfoodeng.2020.109922

Codina-Torrella I, Guamis B, Ferragut V, Trujillo AJ (2017) Potential application of ultra-high pressure homogenization in the physico-chemical stabilization of tiger nuts' milk beverage. Innov Food Sci Emerg Technol 40:42-51. https://doi.org/10. 1016/j.ifset.2016.06.023

Dai J, Mumper RJ (2010) Plant phenolics: extraction, analysis and their antioxidant and anticancer properties. Molecules 15:7313-7352. https://doi.org/10.3390/molecules15107313

de Souza LP, Faroni LRDA, Heleno FF et al (2018) Ozone treatment for pesticide removal from carrots: optimization by response surface methodology. Food Chem 243:435-441. https://doi.org/ 10.1016/j.foodchem.2017.09.134

de Souza VR, Popović V, Bissonnette S et al (2020) Quality changes in cold pressed juices after processing by high hydrostatic pressure, ultraviolet-c light and thermal treatment at commercial regimes. Innov Food Sci Emerg Technol 64:102398. https://doi. org/10.1016/j.ifset.2020.102398

Delfino JR, da Silva JL, Marques ALB, Stradiotto NR (2020) Antioxidants detection in aviation biokerosene by high-performance liquid chromatography using gold nanoparticles anchored in reduced graphene oxide. Fuel 260:116315. https://doi.org/10. 1016/j.fuel.2019.116315

Demirdöven A, Baysal T (2014) Optimization of ohmic heating applications for pectin methylesterase inactivation in orange juice. J Food Sci Technol 51:1817-1826. https://doi.org/10. 1007/s13197-012-0700-5

Dennis R, Cashion A, Emanuel S, Hubbard D (2020) Ozone gas: scientific justification and practical guidelines for improvised disinfection using consumer-grade ozone generators and plastic storage boxes. J Sci Med 2:1-28. https://doi.org/10.37714/josam. v2i1.35

Deshpande VK, Walsh MK (2020) Effect of thermosonication in a continuous system on indigenous microflora, milk quality, and 
consumer acceptance J Food Process Preserv pp. 1-11 https:// doi.org/10.1111/jfpp. 14666

Duhan JS, Kumar R, Kumar N et al (2017) Nanotechnology: the new perspective in precision agriculture. Biotechnol Reports 15:11-23. https://doi.org/10.1016/j.btre.2017.03.002

Echegoyen Y, Rodríguez S, Nerín C (2016) Nanoclay migration from food packaging materials. Food Addit Contam - Part A Chem Anal Control Expo Risk Assess 33:530-539. https://doi.org/10. 1080/19440049.2015.1136844

Fernández PR, Lovera N, Ramallo LA (2020) Sucrose syrup reuse during one- and multi-stage osmotic dehydration of pineapple. J Food Process Eng 43:1-10. https://doi.org/10.1111/jfpe.13399

Filimonau V, De Coteau DA (2019) Food waste management in hospitality operations: a critical review. Tour Manag 71:234-245. https://doi.org/10.1016/j.tourman.2018.10.009

Fisher CW, Lee D, Dodge BA et al (2000) Influence of catalase and superoxide dismutase on ozone inactivation of Listeria monocytogenes. Appl Environ Microbiol 66:1405-1409. https://doi. org/10.1128/AEM.66.4.1405-1409.2000

Fu X, Belwal T, Cravotto G, Luo Z (2020) Sono-physical and sonochemical effects of ultrasound: primary applications in extraction and freezing operations and influence on food components. Ultrason Sonochem 60:104726. https://doi.org/10.1016/j.ult sonch.2019.104726

Funcia ES, Gut JAW, Sastry SK (2020) Effect of electric field on pectinesterase inactivation during orange juice pasteurization by ohmic heating. Food Bioprocess Technol 13:1206-1214. https:// doi.org/10.1007/s11947-020-02478-x

Gabr MH, Okumura W, Ueda H et al (2015) Mechanical and thermal properties of carbon fiber/polypropylene composite filled with nano-clay. Compos Part B Eng 69:94-100. https://doi.org/10. 1016/j.compositesb.2014.09.033

Gaikwad KK, Singh S, Lee YS (2018) Oxygen scavenging films in food packaging. Environ Chem Lett 16:523-538. https://doi.org/ 10.1007/s10311-018-0705-z

Gaikwad KK, Singh S, Negi YS (2020) Ethylene scavengers for active packaging of fresh food produce. Environ Chem Lett 18:269-284. https://doi.org/10.1007/s10311-019-00938-1

Gałązka-Czarnecka I, Korzeniewska E, Czarnecki A et al (2020) Modelling of carotenoids content in red clover sprouts using light of different wavelength and pulsed electric field. Appl Sci 10:4143. https://doi.org/10.3390/app10124143

Gammoh S, Alu'datt MH, Tranchant CC, et al (2020) Modification of the functional and bioactive properties of camel milk casein and whey proteins by ultrasonication and fermentation with Lactobacillus delbrueckii subsp. lactis. LWT 129:109501. doi: https:// doi.org/10.1016/j.lwt.2020.109501

Gao F, Hong F, Liu C et al (2006) Mechanism of nano-anatase $\mathrm{TiO}_{2}$ on promoting photosynthetic carbon reaction of spinach inducing complex of rubisco-rubisco activase. Biol Trace Elem Res 111:239-253. https://doi.org/10.1385/BTER:111:1:239

Gao F, Liu C, Qu C et al (2008) Was improvement of spinach growth by nano- $\mathrm{TiO}_{2}$ treatment related to the changes of rubisco activase? Biometals 21:211-217. https://doi.org/10.1007/ s10534-007-9110-y

Gharibi V, Khanjani N, Heidari H et al (2020) The effect of heat stress on hematological parameters and oxidative stress among bakery workers. Toxicol Ind Health 36:1-10. https://doi.org/10. 1177/0748233719899824

Ghouri MZ, Khan Z, Khan SH et al (2020) Nanotechnology: transformation of agriculture and food security. AJBB 3:1-17. https://doi.org/10.28933/AJBB

Gomez-Zavaglia A, Mejuto JC, Simal-Gandara J (2020) Mitigation of emerging implications of climate change on food production systems. Food Res Int 134:109256. https://doi.org/10.1016/j. foodres.2020.109256
Goud KY, Reddy KK, Satyanarayana M et al (2020) A review on recent developments in optical and electrochemical aptamerbased assays for mycotoxins using advanced nanomaterials. Microchim Acta 187:1-32. https://doi.org/10.1007/s00604-0194034-0

Gracin L, Jambrak AR, Juretić H et al (2016) Influence of high power ultrasound on Brettanomyces and lactic acid bacteria in wine in continuous flow treatment. Appl Acoust 103:143-147. https:// doi.org/10.1016/j.apacoust.2015.05.005

Griffin M, Sobal J, Lyson TA (2009) An analysis of a community food waste stream. Agric Human Values 26:67-81. https://doi. org/10.1007/s10460-008-9178-1

Gu R, Yun H, Chen L et al (2020) Regenerated cellulose films with amino-terminated hyperbranched polyamic anchored nanosilver for active food packaging. ACS Appl Bio Mater 3:602-610. https://doi.org/10.1021/acsabm.9b00992

Han J, Zhang X, He S et al (2020) Can the coronavirus disease be transmitted from food? A review of evidence, risks, policies and knowledge gaps. Environ Chem Lett. https://doi.org/10.1007/ s10311-020-01101-x

Hashemi H, Parastouei K, Mokhtarian M, et al. (2020) Application of innovative processing methods for the extraction of bioactive compounds from saffron (Crocus sativus) petals J Appl Res Med Aromat Plants 100264https://doi.org/10.1016/j.jarmap.2020. 100264

He X, Deng H, Hwang H, min, (2019) The current application of nanotechnology in food and agriculture. J Food Drug Anal 27:1-21. https://doi.org/10.1016/j.jfda.2018.12.002

Hernández-Hernández H, Quiterio-Gutiérrez T, Cadenas-Pliego G et al (2019) Impact of selenium and copper nanoparticles on yield, antioxidant system, and fruit quality of tomato plants. Plants 8:1-17. https://doi.org/10.3390/plants8100355

Hong F, Zhou J, Liu C et al (2005) Effect of nano- $\mathrm{TiO}_{2}$ on photochemical reaction of chloroplasts of spinach. Biol Trace Elem Res 105:269-279. https://doi.org/10.1385/BTER:105:1-3: 269

Hu W, Ye X, Chantapakul T et al (2020) Manosonication extraction of RG-I pectic polysaccharides from citrus waste: optimization and kinetics analysis. Carbohydr Polym 235:115982. https://doi. org/10.1016/j.carbpol.2020.115982

Huang D, Men K, Li D et al (2020) Application of ultrasound technology in the drying of food products. Ultrason Sonochem 63:104950. https://doi.org/10.1016/j.ultsonch.2019.104950

Izquierdo-Cañas PM, Ríos-Carrasco M, García-Romero E et al (2020) Co-existence of inoculated yeast and lactic acid bacteria and their impact on the aroma profile and sensory traits of tempranillo red wine. Fermentation 6:1-13. https://doi.org/10. 3390/fermentation6010017

Jamróz E, Khachatryan G, Kopel P et al (2020) Furcellaran nanocomposite films: the effect of nanofillers on the structural, thermal, mechanical and antimicrobial properties of biopolymer films. Carbohydr Polym 240:116244. https://doi.org/10.1016/j. carbpol.2020.116244

Jayasena DD, Kim HJ, Yong HI et al (2015) Flexible thin-layer dielectric barrier discharge plasma treatment of pork butt and beef loin: Effects on pathogen inactivation and meat-quality attributes. Food Microbiol 46:51-57. https://doi.org/10.1016/j. fm.2014.07.009

Jose T, George SC, Maya MG et al (2014) Effect of bentonite clay on the mechanical, thermal, and pervaporation performance of the poly(vinyl alcohol) nanocomposite membranes. Ind Eng Chem Res 53:16820-16831. https://doi.org/10.1021/ie502632p

Joshi H, Choudhary P, Mundra SL (2019) Future prospects of nanotechnology in agriculture. Int J Chem Stud 7:957-963

Kaphle A, Navya PN, Umapathi A, Daima HK (2018) Nanomaterials for agriculture, food and environment: applications, toxicity and 
regulation. Environ Chem Lett 16:43-58. https://doi.org/10. 1007/s10311-017-0662-y

Karrar E, Sheth S, Wei W, Wang X (2020) Effect of microwave heating on lipid composition, oxidative stability, color value, chemical properties, and antioxidant activity of gurum (Citrulluslanatus var. Colocynthoide) seed oil. Biocatal Agric Biotechnol 23:101504. doi: https://doi.org/10.1016/j.bcab.2020.101504

Khan SA, Dar AH, Bhat, SA et al. (2020) High intensity ultrasound processing in liquid foods. Food Rev Int. pp. 1-25 https://doi. org/10.1080/87559129.2020.1768404

Kulawik P, Jamróz E, Özogul F (2020) Chitosan role for shelf-life extension of seafood. Environ Chem Lett 18:61-74. https://doi. org/10.1007/s10311-019-00935-4

Leisner CP (2020) Review: climate change impacts on food securityfocus on perennial cropping systems and nutritional value. Plant Sci 293:110412. https://doi.org/10.1016/j.plantsci.2020.110412

Li M, Liu HL, Dang F et al (2020) Alteration of crop yield and quality of three vegetables upon exposure to silver nanoparticles in sludge-amended soil. ACS Sustain Chem Eng 8:2472-2480. https://doi.org/10.1021/acssuschemeng.9b06721

Liao H, Zhu W, Zhong K, Liu Y (2020) Evaluation of colour stability of clear red pitaya juice treated by thermosonication. Lwt 121:108997. https://doi.org/10.1016/j.lwt.2019.108997

Lim JH, Sisco P, Mudalige TK et al (2015) Detection and characterization of $\mathrm{SiO}_{2}$ and $\mathrm{TiO}_{2}$ nanostructures in dietary supplements. J Agric Food Chem 63:3144-3152. https://doi.org/ 10.1021/acs.jafc.5b00392

López-Pérez O, del Olmo A, Picon A, Nuñez M (2020) Volatile compounds and odour characteristics during long-term storage of kombu seaweed (Laminaria ochroleuca) preserved by high pressure processing, freezing and salting. LWT 118:108710. https://doi.org/10.1016/j.1wt.2019.108710

Luengo E, Martínez JM, Álvarez I, Raso J (2016) Effects of millisecond and microsecond pulsed electric fields on red beet cell disintegration and extraction of betanines. Ind Crops Prod 84:28-33. https://doi.org/10.1016/j.indcrop.2016.01.016

Luo H, Schmid F, Grbin PR, Jiranek V (2012) Viability of common wine spoilage organisms after exposure to high power ultrasonics. Ultrason Sonochem 19:415-420. https://doi.org/10.1016/j. ultsonch.2011.06.009

Luo Y, Wang Q, Zhang Y (2020) Biopolymer-based nanotechnology approaches To deliver bioactive compounds for food applications: a perspective on the past, present, and future. J Agric Food Chem. https://doi.org/10.1021/acs.jafc.0c00277

Madhusudhana MG, Bhakta AK et al (2020) Bismuth-nanoparticles decorated multi-wall-carbon-nanotubes cast-coated on carbon paste electrode; an electrochemical sensor for sensitive determination of gallic acid at neutral $\mathrm{pH}$. Mater Sci Energy Technol 3:174-182. https://doi.org/10.1016/j.mset.2019.10.001

Makroo HA, Rastogi NK, Srivastava B (2020) Ohmic heating assisted inactivation of enzymes and microorganisms in foods: a review. Trends Food Sci Technol 97:451-465. https://doi.org/10.1016/j. tifs.2020.01.015

Mamadou T, Sun A, Gan Z et al (2019) Antimicrobial capacity of ultrasound and ozone for enhancing bacterial safety on inoculated shredded green cabbage (Brassica oleracea var capitata). Can J Microbiol 66:125-137. https://doi.org/10.1139/cjm-20190313

Margean A, Lupu MI, Alexa E et al (2020) An overview of effects induced by pasteurization and high-power ultrasound treatment on the quality of red grape juice. Molecules 25:1-16. https://doi. org/10.3390/molecules25071669

Meng D, Zuo P, Song H, Yang R (2019) Influence of manothermosonication on the physicochemical and functional properties of ferritin as a nanocarrier of iron or bioactive compounds.
J Agric Food Chem 67:6633-6641. https://doi.org/10.1021/acs. jafc.9b01739

Morin-Crini N, Lichtfouse E, Torri G, Crini G (2019) Applications of chitosan in food, pharmaceuticals, medicine, cosmetics, agriculture, textiles, pulp and paper, biotechnology, and environmental chemistry. Environ Chem Lett 17:1667-1692. https://doi.org/10. 1007/s10311-019-00904-x

Mousavi Khaneghah A, Hashemi Moosavi M, Oliveira CAF et al (2020) Electron beam irradiation to reduce the mycotoxin and microbial contaminations of cereal-based products: an overview. Food Chem Toxicol 143:111557. https://doi.org/10.1016/j.fct. 2020.111557

Nakamura H, Oya M, Hanamoto T, Nagashio D (2017) Reviewing the 20 years of operation of ozonation facilities in Hanshin water supply authority with respect to water quality improvements. Ozone Sci Eng 39:397-406. https://doi.org/10.1080/01919512. 2017.1352413

Naser-Sadrabadi A, Zare HR, Benvidi A (2020) Photochemical deposition of palladium nanoparticles on $\mathrm{TiO}_{2}$ nanoparticles and their application for electrocatalytic measurement of nitrate ions in potato, onion and cabbage using bipolar electrochemical method. Meas J Int Meas Confed 166:108222. https://doi.org/10. 1016/j.measurement.2020.108222

Nayik GA, Nanda V (2016) Effect of thermal treatment and pH on antioxidant activity of saffron honey using response surface methodology. J Food Meas Charact 10:64-70. https://doi.org/10. 1007/s11694-015-9277-9

Ndlovu N, Mayaya T, Muitire C, Munyengwa N (2020) Nanotechnology applications in crop production and food systems. Int $\mathrm{J}$ Plant Breed Crop Sci 7:624-634

Nguyen NT, Lee J, Woo SM, et al (2020) The response of yeast vacuolar proteins: a novel rapid tool for Salmonella $s p$. screening. Biotechnol Appl Biochem 1-12. doi: https://doi.org/ 10.1002/bab. 1910

Nile SH, Baskar V, Selvaraj D et al (2020) Nanotechnologies in food science: applications, recent trends, and future perspectives. Nano-Micro Lett 12:1-34. https://doi.org/10.1007/s40820-0200383-9

Odriozola-Serrano I, Aguiló-Aguayo I, Soliva-Fortuny R, MartínBelloso O (2013) Pulsed electric fields processing effects on quality and health-related constituents of plant-based foods. Trends Food Sci Technol 29:98-107. https://doi.org/10.1016/j. tifs.2011.10.003

Paliwal R, Paliwal SR, Kenwat R et al (2020) Solid lipid nanoparticles: a review on recent perspectives and patents. Expert Opin Ther Pat 30:179-194. https://doi.org/10.1080/13543776.2020. 1720649

Pandiselvam R, Kaavya R, Jayanath Y et al (2020) Ozone as a novel emerging technology for the dissipation of pesticide residues in foods-a review. Trends Food Sci Technol 97:38-54. https://doi. org/10.1016/j.tifs.2019.12.017

Pandiselvam R, Subhashini S, Banuu Priya EP et al (2019) Ozone based food preservation: a promising green technology for enhanced food safety. Ozone Sci Eng 41:17-34. https://doi.org/ 10.1080/01919512.2018.1490636

Parreiras PM, Vieira Nogueira JA, Rodrigues da Cunha L et al (2020) Effect of thermosonication on microorganisms, the antioxidant activity and the retinol level of human milk. Food Control 113:107172. https://doi.org/10.1016/j.foodcont.2020.107172

Pereira RN, Teixeira JA, Vicente AA et al (2018) Ohmic heating for the dairy industry: a potential technology to develop probiotic dairy foods in association with modifications of whey protein structure. Curr Opin Food Sci 22:95-101. https://doi.org/10. 1016/j.cofs.2018.01.014

Peter A, Tegla D, Giurgiulescu L et al (2015) Development of Ag/ $\mathrm{TiO}_{2}-\mathrm{SiO}_{2}$-coated food packaging film and its role in 
preservation of green lettuce during storage. Carpathian J Food Sci Technol 7:88-96

Pradela-Filho LA, Andreotti IAA, Carvalho JHS et al (2020) Glass varnish-based carbon conductive ink: a new way to produce disposable electrochemical sensors. Sensors Actuators, B Chem 305:127433. https://doi.org/10.1016/j.snb.2019.127433

Prakash A (2016) Particular applications of food irradiation fresh produce. Radiat Phys Chem 129:50-52. https://doi.org/10.1016/ j.radphyschem.2016.07.017

Prieto-Santiago V, Cavia MM, Alonso-Torre SR, Carrillo C (2020) Relationship between color and betalain content in different thermally treated beetroot products. J Food Sci Technol 57:3305-3313. https://doi.org/10.1007/s13197-020-04363-z

Qi M, Liu Y, Li T (2013) Nano- $\mathrm{TiO}_{2}$ improve the photosynthesis of tomato leaves under mild heat stress. Biol Trace Elem Res 156:323-328. https://doi.org/10.1007/s12011-013-9833-2

Rahimi S, Mikani M (2019) Lycopene green ultrasound-assisted extraction using edible oil accompany with response surface methodology (RSM) optimization performance: application in tomato processing wastes. Microchem J 146:1033-1042. https:// doi.org/10.1016/j.microc.2019.02.039

Rai M, Ingle AP, Gupta I et al (2019) Smart nanopackaging for the enhancement of food shelf life. Environ Chem Lett 17:277-290. https://doi.org/10.1007/s10311-018-0794-8

Ravindran R, Jaiswal AK (2019) Wholesomeness and safety aspects of irradiated foods. Food Chem 285:363-368. https://doi.org/10. 1016/j.foodchem.2019.02.002

Rech S, Finco E, Lazzaretto A (2020) A multicriteria approach to choose the best renewable refrigeration system for food preservation. Renew Energy 154:368-384. https://doi.org/10.1016/j. renene. 2020.02.115

ReFED (2016) A Roadmap to Reduce U.S. Food Waste by 20 Percent

Ren F, Perussello CA, Zhang Z et al (2018) Impact of ultrasound and blanching on functional properties of hot-air dried and freeze dried onions. LWT - Food Sci Technol 87:102-111. https://doi. org/10.1016/j.lwt.2017.08.053

Režek Jambrak A, Šimunek M, Evačić S et al (2018) Influence of high power ultrasound on selected moulds, yeasts and Alicyclobacillus acidoterrestris in apple, cranberry and blueberry juice and nectar. Ultrasonics 83:3-17. https://doi.org/10.1016/j. ultras.2017.02.011

Riah W, Laval K, Laroche-Ajzenberg E et al (2014) Effects of pesticides on soil enzymes: a review. Environ Chem Lett 12:257-273. https://doi.org/10.1007/s10311-014-0458-2

Roselló-Soto E, Poojary MM, Barba FJ et al (2018) Thermal and nonthermal preservation techniques of tiger nuts' beverage "horchata de chufa". implications for food safety, nutritional and quality properties. Food Res Int 105:945-951. https://doi.org/10. 1016/j.foodres.2017.12.014

Ruivo Da Silva MG, Skrt M, Komes D, et al (2020) Enhanced yield of bioactivities from onion (Allium cepa l.) skin and their antioxidant and anti- $\alpha$-amylase activities. Int J Mol Sci 21:2909 doi: https://doi.org/10.3390/ijms21082909

Sadło S, Szpyrka E, Piechowicz B et al (2017) Reduction of captan, boscalid and pyraclostrobin residues on apples using water only, gaseous ozone, and ozone Aqueous solution. Ozone Sci Eng 39:97-103. https://doi.org/10.1080/01919512.2016.1257931

Said MI (2020) Role and function of gelatin in the development of the food and non-food industry: a review. IOP Conf Ser Earth Environ Sci 492:012086. https://doi.org/10.1088/1755-1315/ 492/1/012086

Salari S, Jafari SM (2020) The influence of ohmic heating on degradation of food bioactive ingredients. Food Eng Rev 12:191-208. https://doi.org/10.1007/s12393-020-09217-0

Salehi F (2020) Physico-chemical properties of fruit and vegetable juices as affected by pulsed electric field: a review. Int $\mathbf{J}$
Food Prop 23:1036-1050. https://doi.org/10.1080/10942912. 2020.1775250

Samadarsi R, Mishra D, Dutta D (2020) Mangiferin nanoparticles fortified dairy beverage as a low glycemic food product: its quality attributes and antioxidant properties. Int J Food Sci Technol 55:589-600. https://doi.org/10.1111/ijfs.14310

Santiago B, Arias Calvo A, Gullón B, et al (2020) Production of flavonol quercetin and fructooligosaccharides from onion $(\mathrm{Al}$ lium cepa $L$.) waste: an environmental life cycle approach. Chem Eng J 392:123772. doi: https://doi.org/10.1016/j.cej.2019. 123772

Saravanan A, Kumar PS, Hemavathy RV et al (2020) Methods of detection of food-borne pathogens: a review. Environ Chem Lett. https://doi.org/10.1007/s10311-020-01072-z

Sarfarazi M, Jafari SM, Rajabzadeh G, Galanakis CM (2020) Evaluation of microwave-assisted extraction technology for separation of bioactive components of saffron (Crocus sativus L.). Ind Crops Prod 145:111978. doi: https://doi.org/10.1016/j. indcrop.2019.111978

Sengar AS, Rawson A, Muthiah M, Kalakandan SK (2020) Comparison of different ultrasound assisted extraction techniques for pectin from tomato processing waste. Ultrason Sonochem 61:104812. https://doi.org/10.1016/j.ultsonch.2019.104812

Seray M, Skender A, Hadj-Hamou AS (2020) Kinetics and mechanisms of $\mathrm{Zn} 2+$ release from antimicrobial food packaging based on poly (butylene adipate-co-terephthalate) and zinc oxide nanoparticles. Polym Bull. https://doi.org/10.1007/s00289-02003145-z

Severino P, Andreani T, Macedo AS et al (2012) Current state-of-art and new trends on lipid nanoparticles (SLN and NLC) for oral drug delivery. J Drug Deliv 2012:1-10. https://doi.org/10.1155/ 2012/750891

Siddeeg A, Manzoor MF, Ahmad MH et al (2019) Pulsed electric field-assisted ethanolic extraction of date palm fruits: bioactive compounds, antioxidant activity and physicochemical properties. Processes 7:585. https://doi.org/10.3390/pr7090585

Silvennoinen K, Katajajuuri JM, Hartikainen H et al (2014) Food waste volume and composition in Finnish households. Br Food J 116:1058-1068. https://doi.org/10.1108/BFJ-12-2012-0311

Sintuya P, Narkprasom K, Jaturonglumlert S et al (2018) Effect of gaseous ozone fumigation on organophosphate pesticide degradation of dried chilies. Ozone Sci Eng 40:473-481. https://doi. org/10.1080/01919512.2018.1466690

Stebel M, Smolka J, Palacz M et al (2020) Numerical investigation of the fluid flow distribution for the hydrofluidisation food freezing method. Int J Therm Sci 151:106284. https://doi.org/10.1016/j. ijthermalsci.2020.106284

Sulistyawati I, Dekker M, Fogliano V, Verkerk R (2018) Osmotic dehydration of mango: effect of vacuum impregnation, high pressure, pectin methylesterase and ripeness on quality. Lwt 98:179-186. https://doi.org/10.1016/j.1wt.2018.08.032

Tamborrino A, Urbani S, Servili M et al (2020) Pulsed electric fields for the treatment of olive pastes in the oil extraction process. Appl Sci 10:114. https://doi.org/10.3390/app10010114

Teng X, Zhang M, Devahastin S (2019) New developments on ultrasound-assisted processing and flavor detection of spices: a review. Ultrason Sonochem 55:297-307. https://doi.org/10.1016/ j.ultsonch.2019.01.014

Tian B, Kou Y, Jiang X et al (2020) Ultrasensitive determination of mercury ions using a glassy carbon electrode modified with nanocomposites consisting of conductive polymer and aminofunctionalized graphene quantum dots. Microchim Acta 187:1-12. https://doi.org/10.1007/s00604-020-4191-1

Tribst AAL, Falcade LTP, Carvalho NS et al (2020) Are stirring and homogenisation processes capable of improving physicochemical and sensory characteristics of stirred yoghurt produced with 
fresh, refrigerated and frozen/thawed sheep milk? Int Dairy J 109:104778. https://doi.org/10.1016/j.idairyj.2020.104778

Tsironi T, Houhoula D, Taoukis P (2020) Hurdle technology for fish preservation. Aquac Fish 5:65-71. https://doi.org/10.1016/j.aaf. 2020.02.001

Venkatasubbu GD, Baskar R, Anusuya T et al (2016) Toxicity mechanism of titanium dioxide and zinc oxide nanoparticles against food pathogens. Colloids Surfaces B Biointerfaces 148:600-606. https://doi.org/10.1016/j.colsurfb.2016.09.042

Verma ML, Dhanya BS, Sukriti, et al (2020) Carbohydrate and protein based biopolymeric nanoparticles: current status and biotechnological applications. Int $\mathrm{J}$ Biol Macromol 154:390-412. https://doi.org/10.1016/j.ijbiomac.2020.03.105

Volkert M, Puaud M, Wille HJ, Knorr D (2012) Effects of high pressure-low temperature treatment on freezing behavior, sensorial properties and air cell distribution in sugar rich dairy based frozen food foam and emulsions. Innov Food Sci Emerg Technol 13:75-85. https://doi.org/10.1016/j.ifset.2011.10.007

Wahia H, Zhou C, Mustapha AT et al (2020) Storage effects on the quality quartet of orange juice submitted to moderate thermosonication: predictive modeling and odor fingerprinting approach. Ultrason Sonochem 64:104982. https://doi.org/10. 1016/j.ultsonch.2020.104982

Wang W, Chen W, Kahraman O et al (2020) Manothermosonication (MTS) treatment by a continuous-flow system: effects on the degradation kinetics and microstructural characteristics of citrus pectin. Ultrason Sonochem 63:104973. https://doi.org/10.1016/j. ultsonch.2020.104973

Wang Y, Zheng Z, Wang K et al (2020) Prebiotic carbohydrates: effect on physicochemical stability and solubility of algal oil nanoparticles. Carbohydr Polym 228:115372. https://doi.org/10. 1016/j.carbpol.2019.115372

Weir A, Westerhoff P, Fabricius L et al (2012) Titanium dioxide nanoparticles in food and personal care products. Environ Sci Technol 46:2242-2250. https://doi.org/10.1021/es204168d

Wibowo S, Essel EA, De Man S et al (2019) Comparing the impact of high pressure, pulsed electric field and thermal pasteurization on quality attributes of cloudy apple juice using targeted and untargeted analyses. Innov Food Sci Emerg Technol 54:64-77. https://doi.org/10.1016/j.ifset.2019.03.004

Wiktor A, Nowacka M, Dadan M et al (2016) The effect of pulsed electric field on drying kinetics, color, and microstructure of carrot. Dry Technol 34:1286-1296. https://doi.org/10.1080/ 07373937.2015.1105813

Wu Y, An Q, Li D et al (2019) Comparison of different home/commercial washing strategies for ten typical pesticide residue removal effects in kumquat, spinach and cucumber. Int J Environ Res Public Health 16:1-20. https://doi.org/10.3390/ ijerph16030472

Wurlitzer NJ, Dionísio AP, Lima JR et al (2019) Tropical fruit juice: effect of thermal treatment and storage time on sensory and functional properties. J Food Sci Technol 56:5184-5193. https:// doi.org/10.1007/s13197-019-03987-0

Xiong ZQ, Cao LR, Wang GQ et al (2020) Isolation of biogenic amine-negative lactic acid bacteria for Chinese rice wine fermentation based on molecular marker reverse screening. J Sci Food Agric 100:3257-3261. https://doi.org/10.1002/jsfa. 10290

Xu H, Zhang Y, He C (2007) Ultrasonically assisted extraction of isoflavones from stem of Pueraria lobata (Willd.) Ohwi and its mathematical model. Chinese J Chem Eng 15:861-867. https:// doi.org/10.1016/s1004-9541(08)60015-4

Yadav S, Mehrotra GK, Dutta PK (2021) Chitosan based ZnO nanoparticles loaded gallic-acid films for active food packaging. Food Chem 334:127605. https://doi.org/10.1016/j.foodchem. 2020.127605
Yang J, Yang M, Qin J et al (2020) Effect of ultrasound on the structural characteristics of fresh skim milk. Food Sci Technol Int 26:222-230. https://doi.org/10.1177/1082013219879257

Yata VK, Tiwari BC, Ahmad I (2018) Nanoscience in food and agriculture: research, industries and patents. Environ Chem Lett 16:79-84. https://doi.org/10.1007/s10311-017-0666-7

Ye Y, Ji J, Sun Z et al (2020) Recent advances in electrochemical biosensors for antioxidant analysis in foodstuff. TrAC - Trends Anal Chem 122:115718. https://doi.org/10.1016/j.trac.2019. 115718

Yemmireddy VK, Hung YC (2015) Effect of binder on the physical stability and bactericidal property oftitanium dioxide $\left(\mathrm{TiO}_{2}\right)$ nanocoatings on food contact surfaces. Food Control 57:82-88. https://doi.org/10.1016/j.foodcont.2015.04.009

Yeom HW, Evrendilek GA, Jin ZT, Zhang QH (2004) Processing of yogurt-based products with pulsed electric fields: Microbial, sensory and physical evaluations. J Food Process Preserv 28:161-178. https://doi.org/10.1111/j.1745-4549.2004.tb00818. $\mathrm{x}$

Yildiz G, Izli G, Aadil RM (2020) Comparison of chemical, physical, and ultrasound treatments on the shelf life of fresh-cut quince fruit (Cydonia oblonga Mill.). J Food Process Preserv 44:1-12. https://doi.org/10.1111/jfpp.14366

Yildiz H, Baysal T (2006) Effects of alternative current heating treatment on Aspergillus niger, pectin methylesterase and pectin content in tomato. J Food Eng 75:327-332. https://doi.org/10. 1016/j.jfoodeng.2005.04.020

Yousuf B, Qadri OS, Srivastava AK (2018) Recent developments in shelf-life extension of fresh-cut fruits and vegetables by application of different edible coatings: a review. LWT - Food Sci Technol 89:198-209. https://doi.org/10.1016/j.lwt.2017.10.051

Yu Y, Jin TZ, Xiao G (2017) Effects of pulsed electric fields pretreatment and drying method on drying characteristics and nutritive quality of blueberries. J Food Process Preserv 41:1-9. https://doi.org/10.1111/jfpp.13303

Yuan G, Chen X, Li D (2016) Chitosan films and coatings containing essential oils: the antioxidant and antimicrobial activity, and application in food systems. Food Res Int 89:117-128. https:// doi.org/10.1016/j.foodres.2016.10.004

Zahedi SM, Karimi M, Teixeira da Silva JA (2020) The use of nanotechnology to increase quality and yield of fruit crops. J Sci Food Agric 100:25-31. https://doi.org/10.1002/jsfa.10004

Zarei M, Fazlara A, Tulabifard N (2019) Effect of thermal treatment on physicochemical and antioxidant properties of honey. Heliyon 5:01894. https://doi.org/10.1016/j.heliyon.2019.e01894

Zendeboodi F, Khorshidian N, Mortazavian AM, da Cruz AG (2020) Probiotic: conceptualization from a new approach. Curr Opin Food Sci 32:103-123. https://doi.org/10.1016/j.cofs.2020.03.009

Zhang X, Xiao G, Wang Y et al (2017) Preparation of chitosan- $\mathrm{TiO}_{2}$ composite film with efficient antimicrobial activities under visible light for food packaging applications. Carbohydr Polym 169:101-107. https://doi.org/10.1016/j.carbpol.2017.03.073

Zhong Z, Xiong YL (2020) Thermosonication-induced structural changes and solution properties of mung bean protein. Ultrason Sonochem 62:104908. https://doi.org/10.1016/j.ultsonch.2019. 104908

Zhu Z, Li Y, Sun DW, Wang HW (2019) Developments of mathematical models for simulating vacuum cooling processes for food products-a review. Crit Rev Food Sci Nutr 59:715-727. https://doi.org/10.1080/10408398.2018.1490696

Zhu Z, Zhang Y, Zhang Y et al (2019) Preparation of PAN@ $\mathrm{TiO}_{2}$ Nanofibers for fruit packaging materials with efficient photocatalytic degradation of ethylene. Materials (Basel) 16:896. https:// doi.org/10.3390/ma12060896

Zorraquín-Peña I, Cueva C, Bartolomé B, Moreno-Arribas MV (2020) Silver nanoparticles against foodborne bacteria. Effects at 
intestinal level and health limitations. Microorganisms 8:132 doi: https://doi.org/10.3390/microorganisms8010132

Zou J, Xu M, Tang W et al (2020) Modification of structural, physicochemical and digestive properties of normal maize starch by thermal treatment. Food Chem 309:125733. https://doi.org/ 10.1016/j.foodchem.2019.125733

Zubair M, Ullah A (2020) Recent advances in protein derived bionanocomposites for food packaging applications. Crit Rev
Food Sci Nutr 60:406-434. https://doi.org/10.1080/10408398. 2018.1534800

Publisher's Note Springer Nature remains neutral with regard to jurisdictional claims in published maps and institutional affiliations. 